
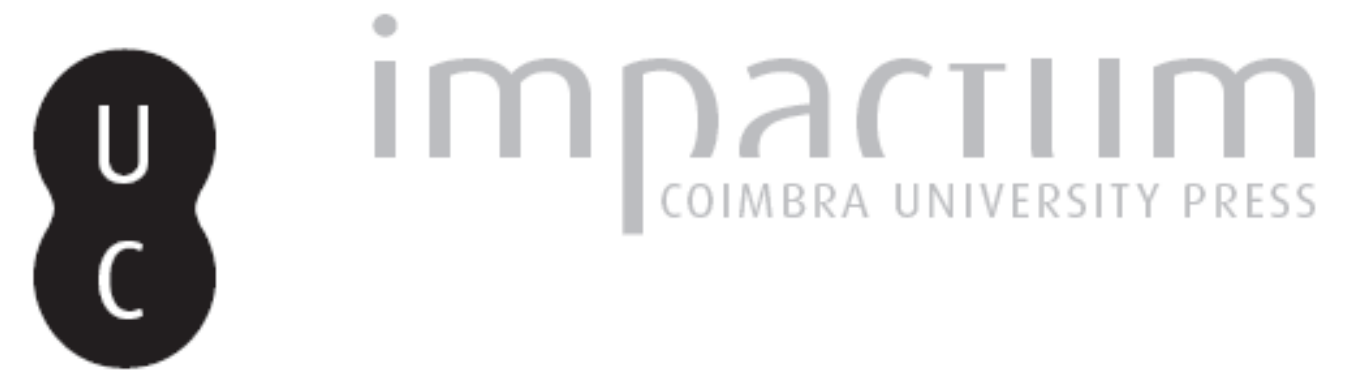

\title{
As mortes de Antero de Quental:"autópsia"de um suicídio
}

Autor(es): $\quad$ Flores, Francisco Moita

Publicado por: Imprensa da Universidade de Coimbra

URL persistente:

URI:http://hdl.handle.net/10316.2/43750

DOI:

DOI:https://doi.org/10.14195/2183-8925_13_13

Accessed : $\quad$ 26-Apr-2023 14:48:18

A navegação consulta e descarregamento dos títulos inseridos nas Bibliotecas Digitais UC Digitalis, UC Pombalina e UC Impactum, pressupõem a aceitação plena e sem reservas dos Termos e Condições de Uso destas Bibliotecas Digitais, disponíveis em https://digitalis.uc.pt/pt-pt/termos.

Conforme exposto nos referidos Termos e Condições de Uso, o descarregamento de títulos de acesso restrito requer uma licença válida de autorização devendo o utilizador aceder ao(s) documento(s) a partir de um endereço de IP da instituição detentora da supramencionada licença.

Ao utilizador é apenas permitido o descarregamento para uso pessoal, pelo que o emprego do(s) título(s) descarregado(s) para outro fim, designadamente comercial, carece de autorização do respetivo autor ou editor da obra.

Na medida em que todas as obras da UC Digitalis se encontram protegidas pelo Código do Direito de Autor e Direitos Conexos e demais legislação aplicável, toda a cópia, parcial ou total, deste documento, nos casos em que é legalmente admitida, deverá conter ou fazer-se acompanhar por este aviso.

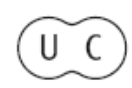


REVISTA DE HISTÓRIA DAS IDEIAS 13

\section{Antero de Quental}

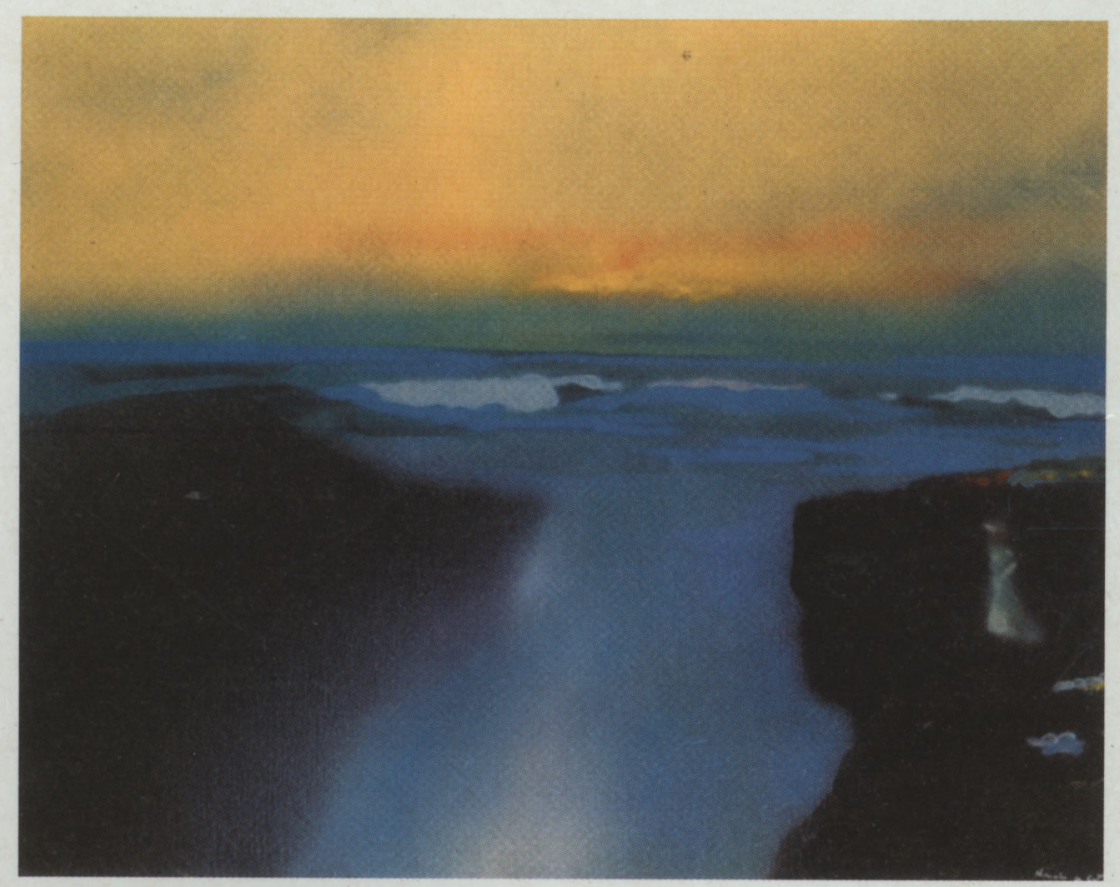

INSTITUTO DE HISTÓRIA E TEORIA DAS IDEIAS FACULDADE DE LETRAS

COIMBRA 1991 


\section{AS MORTES DE ANTERO DE QUENTAL "Autópsia" de um Suicídio}

"Este homem, fundamentalmente bom, se tivesse vivido no século VI ou no século $X I I I$ seria um dos companheiros de S. Bento ou de. S. Francisco de Assis. No século XIX é. um excêntrico..."

J. P. Oliveira Martins

Algumas interrogações prévias

Porque se suicidou Antero? O enigma da sua morte que explicações encerra? Como morreu este Homem, cuja obra é decisiva para a compreensão do Portugal de "fin de siecle", e na perspectiva de Gaspar Simões $\left({ }^{1}\right)$, interprete catalítico das pulsões complexas que a sua Geração libertou e sacudiram a trajectéria cultural portuguesa? Quem morreu? Um homem doente, derrotado e destruído, ou um filosofo inacabado ou um místico confiante numa escatologia imanentista da Morte? Ou então, citando Sousa Martins ( $\left.{ }^{2}\right)$ : "Foi livre Antero, na

* Doutorando em História.

(') "Teria existido a 'geração de 70' sem Antero de Quental? (...) Existiu e existiria, com ou sem Antero, a 'geração de 70'. Mas sem ele, existiria, talvez de outra maneira" (Cf. João Gaspar Simões, A Geração de 70. Alguns Tópicos para a sua História, Lishoa, Ed. Inquérito, Cad. Cult., pp. 64-68).

${ }^{(2)}$ "Nosographia de Anthero" in Anthero de Quental - In Memorian, Porto, Mathieu Lugan, 1896, pp. 309-310. 
escolha do momento? Foi livre, ao menos, na escolha do processo da morte?"

Por fim, uma última questão: o suicídio do pocta-filósofoé um mero instante, um episódio, ou terá sido o eṕlogo de uma vida que se consumiu em suicídios sucessivos, entendidos como amputações conscientemente autodeterminadas, num processo de conflitualidade dialéctica entre os limites temporais da existência e a necessidade da apreensão metafísica da sua própria essência? ( $\left.{ }^{3}\right)$

A consciência da finitude e o desejo da amortalidade confluem dramaticamente no momento da morte biológica e, particularmente, quando ela não só é desejada como definitivamente assumida pelo suicida. Em Antero, como veremos, este "assassinato de si próprio" é, de certa forma, a assunção gnosiológica da impossibilidade da vida biológica infinita $\left({ }^{4}\right)$ articulada na crença da perpetuação pampsiquista da existência $\left(^{5}\right)$.

Este suicídio, por outro lado, reveste-se de peculiaridades que escapam aos modelos explicativos que, desde o séc. XIX, têm procurado aprofundar a compreensão do acto suicidário. $\mathrm{Na}$ casuística que conhecemos, da ainda muito incompleta história do suicídio $\mathrm{cm}$ Portugal, não encontrámos qualquer outro exemplo que nos permitisse cotejos que propiciassem maior aproximação ao objecto do nosso estudo. Acrescente-se a esta dificuldade, muitas outras decorrentes das especificidades do local onde se consumou o suicídio - Ponta Delgada -, da singularidade do personagem, dos múltiplos aproveitamentos que, de imediato, a sua morte e obra tiveram, tantas vezes para fins de natureza duvidosa.

(3) "Du coeur même de l'empiricité, s'indique l'obligation de remonter (...) jusqu'à une analy tique de la finitude, où l'ĉtre de l'homme pourra fonder en leur positivité toutes les formes que lui indiquent qu'il n'est pas infini" (Michel Foucault, Les mots et les choses, Ed. Gallimard, 1986, p. 326).

(4) "L'expćrience qui se forme au début du XIX' Siècle loge la découverte de la finitude, non plus à l'intérieur de la pensée de l'infini, mais ao coeur même de ces contenus qui sont donées par un savoir fini, comme les formes concrétes de l'existence fin", (Idem, ibidem, p. 327).

(5) "A comunidade de pensamentos não a dissolvem os mares e os continentes entrepostos, porque dos mais arredados pontos da terra se vê sempre o alto sítio do céu aonde os espíritos pelo fitarem com um mesmo e comum amor se juntam e unem indissoluvelmente" ("Carta n. ${ }^{8} 29$, a Francisco Machado Faria e Maia, fins de 1865 " in Antero de Quental, Cartas I (1852-1881), Organização, introdução e notas de Ana Maria Almeida Martins, Lisboa, Ed. Comunicação/Universidade dos Açores, 1989. 
Se durante a vida fora o "príncipe da mocidade", o "condottieri" de uma "geração sem programa", mas ideologicamente prolígera, a morte submeteu-o a rituais mitificantes acrescentando-lhe atributos tão subjectivos quanto quiméricos. Descortinar Antero, através desta nebulosa etérea exigiu-nos um esforço frio e distanciado que, atravessando as liturgias beatificantes de parte substancial da sua imortalidade, nos deixasse vislumbrar o homem carnal e mortal. Não se deduza do exposto, a procura da "humanidade" de Antero. Foi outro o nosso fim. Empenhámo-nos na pesquisa dos scus comportamentos e atitudes destrutivas que lhe marcaram o caminho para a morte.

Decorreram várias décadas para que um biógrafo ousasse sondar com maior profundidade a vida e obra de Antero ( $\left.{ }^{6}\right)$. Não obstante a exaustão com que Bruno Carreiro documenta o percurso biográfico de Antero, é compreensf́vel que a reconstituição factual a que o autor se propõe, particularmente no que respeita à morte, apresente algumas omissões. No entanto, é à sua hermenêutica, que tem sido generalizadamente aceite, que pomos algumas reservas e nos levam à releitura do seu importante espólio documental (). Tal esforço não teria sido possível sem o contributo generoso e solidário do $\mathrm{Dr}$. Francisco da Costa Santos, Dr. Jorge da Costa Santos, dos peritos João Figueiredo e Fernando Almeida, cuja amizade fraternal construímos $\mathrm{cm}$ combates de muitos anos, ao lado da Vida contra a Morte $\left(^{8}\right)$.

Por fim, e sobrctudo, um agradecimento especial ao Prof. Fernando Catroga, que nos incitou a enfrentar e a vencer alguns fantasmas, e forneceu indicaçðes fundamentais para a elaboração do presente estudo.

Chegados aqui, retornemos à questão central: Porque se matou

${ }^{(6)}$ José Bruno Carrciro, Antero de Quental. Subsidios para a sua Biografia, Ponta Delgada, Instituto Cultural de Ponta Delgada, 1948, 2 vols.

() As fontes a que José Bruno Carreiro recorre, são, sobretudo, depoimentos recolhidos em contemporâneos de Antero, relatórios claborados a propósito da sua morte, a imprensa da época e à literatura subsequente com realce para olnMemoriam.

$\left({ }^{8}\right)$ Os irmãos Costa Santos são médicos do Instituto de Medicina Legal de Lisboa (ver entrevista em Apêndices. João Figueiredo c Fernando Almeida são peritos de balística e armamento, o último do LPC da Polícia Judiciária. Finalmente, um agradecimento especial a António Valdemar, jornalista e membro da Direç̧ão de Serviços de Investigaçãoe Actividade Cultural da Biblioteca Nacional que nos auxiliou na revisão do texto e forneccu algumas pistas para futuras investigações sobre o "Antero católico". 
Antero de Quental? Como se suicidou? A sua trajectória existencial marca-lhe alguns encontros com a predisposição para o suicídio, ou foi um desmembramento contínuo das suas capacidades fundamentais, até ao momento lúcido e decisivo, ocorrido nessa noite centenária de 11 de Setcmbro de 1891 ?

\section{A morte biológica de Antero de Quental}

\section{1. A tomada da decisāo suicida}

A última carta que se conhece de Antero de Quental é datada de 29 de Agosto de $1891\left(^{(}\right)$. Marcada pela angústia e pelo desespero é manifesta a depressão que, nos dias seguintes, vai ser determinante para a comprecnsão do acto suicida.

No entanto, treze dias antes, não existe qualquer indício que nos permita perceber o descnlace. O propósito cra regressar a Lisboa, viagem que contava realizar no dia 18 de Setembro do mês seguinte. A crise depressiva que confessava ao seu amigo Oliveira Martins não cra uma novidade. Se lermos com atenção o cpistolário antcriano verificaremos que o estado de espírito que descrevia se repete, intermitentemente ao longo dos últimos trinta anos, com particular incidência depois de 1874, quando a sua doença (ou doenças) se manifestou com maior cvidência.

Aproximemo-nos um pouco mais desta importante carta. A primcira questão que coloca $\mathfrak{e}$ a do agravamento da doença, preocupação prioritária do rol de inquictações que o atormentam. Tal facto justifica a decisão de regressar ao continente para, $\mathrm{cm}$ Lisboa, viver na companhia de sua irmã Ana de Quental. Lamenta, depois, que a falta de saúde impeça a exccução do projeclo com que partira para S. Miguel: fixar-se delinitivamente na ilha. A consciência da frustração deste desígnio fá-lo novamente deplorar a doença - "É um desgosto e transtorno de cujo abalo não sci se poderei jamais restabclecer-me" (Cf. nota supra). De seguida, dá conta das preocupaçóes que lhe merecem as filhas adoptivas Albcrtina e Beatriz Mcircles, impossibilitadas de 0 acompanharem porque o estado de saúde da irmã não lhe permite

(9) Carlas II, ob. cit., c. 690, a Oliveira Martins, 29 de Agosto de 1891, p. 1067. 
ocupar-se da sua educação, "e depois terá ela saúde e vida? E eu?". Comunica a Oliveira Martins que encontrou uma "famflia pobre e honesta" que vai tomar conta das raparigas e regressa ao lamento de ter decidido estabelecer-se em Ponta Delgada, para terminar tornando a revelar a sua doença.

Agora recuemos alguns dias, a 10 de Agosto, quando escreve a Gustavo Barbosa $\left({ }^{10}\right)$, noticiando que a irmã e as crianças chegaram bem a S. Miguel. Antero está contente e a saúde não o preocupa sobremaneira. "De saúde, vou-me restabelecendo, gradualmente: a aclimação não se faz num dia, mas o importante é que se vai fazendo".

Nos finais de Julho, alguns dias antes da chegada da família, sentia-se de tal forma indisposto que escreve de Ponta Delgada para Ponta Delgada, a Eugénio Vaz Pacheco do Canto e Castro $\left({ }^{11}\right)$, "Bastante incomodado de saúde, não me é possível por ora, ir agradecer pessoalmente a V. Ex..".

Nestas três breves indicaçð̃es é possível captar a curva sinusoidal do estado de espírito de Antero. A solidão, a ausência de conforto afectivo que experimentara durante o Verão $\left({ }^{12}\right)$, ansioso pela chegada da famllia, agravara-lhe os sinais de morbosidade, para renascer alegremente depois do reencontro com a irmã e as filhas adoptivas. Porém, frustrados os objectivos a que se propusera, em grande prostração pessimista, comunica a Oliveira Martins que vai regressar ao continente.

Antero chegava à definitiva conclusão de que lhe era impossível ser o bonus pater familia que desejara ao abandonar Vila do Conde, no ano anterior. A frieza dos parentes mais próximos, a rebeldia da pequena Beatriz $\left({ }^{13}\right)$, a incapacidade para compatibilizar a instabilidade que lhe exigiria a vida familiar, condu-lo à dramática conclusão de que a unidade nuclear onde procurava refúgio afectivo e emocional, era impossível.

Não devemos sobrevalorizar as tão empoladas questiúnculas entre

$\left({ }^{10}\right)$ Ibidem, c. 690, a Gustavo Barbosa, 10 de Agosto de 1891, p. 1067.

(11) Ibidem, c. 689, a Eugénio Vaz Pacheco do Canto e Castro, 31 de Julho de 1891, p. 1066.

$\left.{ }^{12}\right)$ Bruno Carreiro descreve com muitos pormenores e bom aparato documental a chegada de Antero a S. Miguel. Inicialmente instalara-se no Hotel Brown. Em finais de Agosto mudou-se para a residência de José Bensaúde (Cf. ob. cit., pp. 264-267).

$\left({ }^{13}\right)$ Cf. Carta a Ana de Quental, Cartas II, ob. cit., c. 676, pp. 1053-1054. 
Antero e a irmã Ana, e, assim, destacá-las como decisivas no encaminhamento para o suicídio. Consideramos que importa nesta última impossibilidade, decorrente da inviabilidade de construir uma estrutura familiar estável, a evidência da doença que durante anos 0 perseguira e, que agora, dava fortes sinais de rápido agravamento.

As tão vincadas e repetidamente invocadas disputas com Ana de Quental a propósito das irmãs Meireles, e tomadas como decisivas para a tomada da decisão suicida, carecem de sustentação, se verificarmos com serenidade os últimos passos da relação entre os irmãos, e de Ana com as raparigas.

Em carta de 13 de Junho de $1891\left({ }^{14}\right)$, logo após a chegada à ilha, Antero dirige-se-lhe preocupado, poderíamos mesmo afirmar, angustiado pelo facto de quando partiu de Lisboa ter percebido 0 profundo desgosto da irmã, mediante a sua decisão de se fixar $\mathrm{cm} S$. Miguel. "Lembro-me do grande desgosto que te dei com a minha partida, mas não te aflijas mais, talvez isto não passe de uma viagem de Verão", e noutro passo da mesma carta, "Como passarias naquele cruel dia 5 e nos seguintes? (...) Bem podes crer que só por considerações superiores tomei uma resolução tão penosa para o meu coração. Quando penso em ti chego a arrepender-me, mas a razão diz-me logo que embora penoso era forçoso. Mas se a natureza se opuser a que cu realize o que me pareceu razoávcl, então nunca mais me separarei de ti".

Três dias depois, torna a escrever $\left({ }^{15}\right)$, "O estado $\mathrm{cm}$ que te deixei não se me tira do pensamento; c quando me lembro que com a minha saída ainda mais o agravei, sinto uma grande tristeza. Mas bem sabes que se razoavclmente cu pudesse ficar ấ, tê-lo-ia feito de todo o coração. Se tiver de voltar, apesar da consolação de me reunir contigo, considerarei isso como uma verdadcira calamidade".

Que podemos concluir? Em primeirolugar a manifesta solidariedade e ternura de Antero para com a irmã. Não há qualquer vislumbre de azedume, nem se pode qualificar apenas de cordialidade a intensidade dos sentimentos que atravessam a cpístola. Depois, justifica a "resolução penosa" pela irrazoabilidade de permanecer no Continente. Ora é sabido que a decisão de sc radicar cm Ponta Delgada está relacionada

(14) Cartas II, ob. cit., c. 675, a Ana de Quental, p. 1047.

(15) Ibidem, c. 675, a Ana de Quental, p. 1049. 
com a futura educação das irmãs Albertina e Beatriz Meireles. No entanto, não só na correspondência com a irmã, mas em cartas do mesmo período a outros amigos, nomeadamente a José Sampaio e a Oliveira Martins, ainda considera transitória a sua permanência em S. Miguel. Procura aclimatar-se, procura uma residência e da satisfação destas duas necessidades dependerá a decisão de ficar ou regressar. Por outro lado, Ana de Quental deslocar-se-á a Ponta Delgada, acompanhando as duas raparigas que haviam ficado consigo em Lisboa, demorando-se ali "dois ou três meses". Quer isto significar que o projecto de Antero desenhava um futuro com uma família a três, isto é, ele e as raparigas.

Não encontramos em qualquer carta indícios da tão propalada discórdia entre os dois irmãos, motivados no facto de Ana condenar asperamente o irmão, por ter aceite a tutela das irmãs orfãs. Aliás, quando em finais de Junho responde a uma carta dela, que lhe terá feito queixas àcerca da irreverência de Beatriz Meireles, claramente toma o partido da irmã, repreendendo a rapariga. "Estou muito sentido com ela, e por isso, enquanto não souber que mudou de comportamento, resolvi suspender-lhe a minha benção" $\left.{ }^{16}\right)$.

$\mathrm{Na}$ verdade, Bruno Carreiro também dá conta de desaguisados que terão existido entre Antero e uma tia dele, por causa da Beatriz, e José Bensaúde, citado por aquele biografo, informa das desavenças entre Ana de Quental e a rapariga que, ao tempo, contava 11 anos. Estes conflitos esporádicos não nos permitem pela generalização de serem as filhas adoptivas de Antero um pólo de conflitos com a irmã. Diga-se até, que, em finais de Agosto, a poucos dias do suicídio, numa altura em que a saúde de Antero dava preocupantes sinais de deterioração, Ana de Quental está em Água de Pau, localidade distante uma dúzia de quilómetros de Ponta Delgada, em casa da irmã Maria Ermelinda, para onde ele escreve $\left({ }^{17}\right)$. O teor da carta não deixa perceber qualquer azedume nas relações entre ambos. Comunica-lhe que decidiu voltar ao Continente, alegra-se pelas melhoras dela e informa-a que optou por deixar Albertina Meireles em Ponta Delgada. Depois, queixando-se da saúde, despede-se "recebe um apertado abraço do teu Irmão do Coração".

(16) Ibidem, c. 680, a Gustavo Barbosa, p. 1055.

(17) Ibidem, c. 692, a Ana de Quental, p. 1069. 


\section{Antero de Quental}

É natural que os conflitos entre Beatriz e os parentes de Antero o inquietassem, e eventualmente terão contribuído para acelerar o crescente agravamento dos distúrbios afectivos que lhe minavam a saúde.

Bruno Carreiro $\left({ }^{18}\right)$ informa que a partir dos finais de Julho há um súbito agravamento da doença. Insónias, diarreias, digestões difíceis e muitas vezes não realizadas, vomitando os alimentos; aparece-lhe um problema de tenesmo e não come mais de uma vez por dia. Ainda seguindo aquele biografo, citando João Machado Faria e Maia, informa que a capacidade de concentração de Antero diminuíra drasticamente a partir dos finais de Agosto, lendo pouco, discutindo superficialmente, desinteressado das grandes questões que toda a vida 0 fascinaram. Começou a alimentar o receio de enlouquecer, tal como acontecera a seu irmão André, ou, então, de ficar paralítico.

José Bensaúde recorda que o ouviu desejar que uma febre tifóide o matasse "porque não tinha coragem para se suicidar". Noutros termos, mas com o mesmo sentido, poucos dias antes do suicídio, di-lo ao seu médico $\left({ }^{19}\right)$ : - "O doutor quer ser meu amigo... muito meu amigo? É dar-me uma dessas injecções que se dão com uma seringa por debaixo da pele e que matam instantaneamente, sem se sentir".

Esta situação derrapante do estado de saúde é confirmado pela correspondência que escreve de Ponta Delgada. Conhecem-se dezanove cartas, desde 13 de Junho a finais de Agosto de 1891. Em doze fala do seu estado de saúde e é perceptível que à medida que os dias passam, o tom epistolar é mais dramático e preocupante.

A perspectiva de separação das raparigas, para além da profunda mágoa que lhe provoca, contribui para agravar a desorientação. Não pode levá-las para Lisboa devido ao estado de saúde, não pode ficar na ilha porque assim, pensa ele, não melhorará. A separação é inevitável e o sonho de uma velhice patriarcal, no remanso da terra natal é impossível. "Procurava o definitivo e afinal ainda agravei o instável e provisorio que tanto me assustava", confidencia a Oliveira Martins. No entanto, se olharmos com atenção o percurso existencial de Antero, não seremos levados a considerar que o caldo da sua vida foi sempre

$\left({ }^{18}\right)$ José Bruno Carreiro, ob. cit., 2. ${ }^{\circ}$ vol., p. 271 e ss.

$\left({ }^{19}\right)$ Ibidem, $2 .^{\circ}$ vol., p. 281. 
o "instável e provisório", sem soluçð̃es definitivas, quase diriamos temeroso de se adaptar a soluçðes definitivas? Como deveremos, então, entender as tempestades interiores que o mortificaram, a não ser pela sua propria incapacidade em aceitar a estabilidade? Pensamos que poreste fio de pensamento perceberemos a variabilidade ziguezagueante de humores, onde se enquadra a decisão de partir para S. Miguel e logo perceber que tal conduta fora imprudente.

Perturbado, torturado pela frustração das expectativas goradas, decide tornar a Lisboa. No entanto, no interior da desorientação, a decisão do suicídio não se afigura. A tonalidade hipocondríaca da sua personalidade, exacerbada pela ansiedade de origem psicopatológica, deve ser considerada no contexto da decisão de deixar S. Miguel. Antero quer fugir, e saindo da ilha, subjectivamente deseja fugir de si: da irritabilidade, da tortura da insónia, das doenças do estômago, da dramática ausência de afecto.

Os testemunhos de Francisco Machado Faria e Maia, visitado por Antero dois dias antes do suić́dio, e do irmão João Faria e Maia, que o recebeu na véspera, são claros: a qualquer dos dois, o comportamento do velho amigo comum não lhes forneceu a menor indicação de que estaria a preparar o suicídio $\left({ }^{20}\right)$. Antero quer fugir e não morrer.

É José Bensaúde, quanto a nós, que acerta em chcio no momento da tomada da decisão suicida, exactamente no dia 11 de Setembro. No Relatório que elaborou para Oliveira Martins, publicado na Seara Nova de 12 de Maio de 1932, e no qual Bruno Carreiro se baseia $\left({ }^{21}\right)$, esclarece a situação. Nesse dia, depois de almoço, começou a solidificar a decisão de pôr termo à vida. Do que se sabe (e pouco se sabe), fica a convicção de que o acto suicidário foi lúcido e conscientemente assumido $\left({ }^{22}\right)$. As cautelas da preparação, nomeadamente a compra da arma, as visitas que durante a tarde faz a parentes e amigos, a paciente espera da noite, para nela encontrar o refúgio tranquilo para o encontro com a morte, a preocupação $\mathrm{cm}$ assumir atitudes quc, de alguma forma, pudessem denunciar a decisão tomada, tudo converge para que nada possa obstaculisar o propósito que deliberadamente assumiu. Às 20

$\left({ }^{20}\right)$ Cf. nota 18 .

(21) José Bruno Carreiro, ob. cit., p. 283.

${ }^{\left({ }^{2}\right)}$ Quer o já referido Relatório José Bensaúde quer a carta publicada por Alice Modemo no In Memoriam (pp. 204-206) mostram que entrc as 15 e as 18 horas do dia 11 , a decisão suicidária estava tomada. 
horas desse mesmo dia, disparava contra si e, uma hora depois, morria no hospital da sua cidade natal e... mortal.

\subsection{O Suicídio}

Antero de Quental escolhcu o Campo de S. Francisco, limitado a norte pelo Convento da Esperança e a uma escassa centena de metros do hospital, para se suicidar $\left({ }^{23}\right)$. Era já noite, que caíra "pesada e nevoenta", com chuviscos e um valor higrométrico de $94 \%$ às 21 horas $\left({ }^{24}\right)$.

O banco de jardim, onde se senta, fica na zona mais afastada, do agora rebaptizado Largo 5 de Outubro, junto ao muro do Convento e sobre o qual, na parede, está gravada a palavra "Esperança". Consigo não tem nada de valor, além de um pacote de bismuto ${ }^{25}$ e o revólver Lefaucheux, que comprara horas antcs. Não deixa mensagem ou carta de despedida. O local, ainda que público, está deserto. Bruno Carreiro conta que um traseunte passa junto a Antero, que está scntado c nada lhe indicia o que vai acontecer $\left.{ }^{26}\right)$. Mais ninguém o vê naquela postura, a não ser depois do disparo fatídico.

Portanto, Antero de Quental isola-se. Não procura o suicídio-espectáculo. Privado da intimidade da sua própria casa, a intimidade da noite é o espaço recolhido, para o último diálogo consigo próprio, e o Campo de S. Francisco, local onde procurava, como adiante veremos, o reencontro com a sua raiz, fica ligado à tragédia da decisão suicidária.

Ninguém sabe como foram esses instantes, nem dos conflitos e tempestades que desabaram dentro de si. Só ele ficou a saber a razão do acto que ia cometer e da escolha do momento, que por enigmáticos, se tornaram porta entreaberta à especulação posterior. Fiquemo-nos, por isso, naquilo que é possível reconstituir a partir da hermenĉutica da prova.

São 20 horas. Antero de Quental leva o revólver à boca, cm posição invertida, isto $\hat{e}$, com a ponta da coronha para fora, e o polcgar dircito no gatilho; encosta o cano da arma ao palato ósseo e dispara. O tiro, desferido de baixo para cima, imprime ao projéctil uma trajectória com

\footnotetext{
(23) Veja-se capítulo deste trabalho "Morte de Homem".

$\left({ }^{24}\right)$ José Bruno Carreiro, ob. cit., p. 417.

(25) V. Apêndice - Entrevista Francisco Costa Santos.

$\left({ }^{26}\right)$ José Bruno Carreiro, ob. cit., p. 287.
} 
entrada pela abóbada palatina e saída pclos ossos do dorso do nariz, abaixo da articulação com o osso frontal $\left({ }^{27}\right)$.

A lesão produzida pelo disparo é causa suficiente e, para a época, necessária da morte.

Quanto a nós, não foi executado o segundo tiro que Mont'Alverne Sequeira refere a José Bruno Carreiro $\left({ }^{28}\right)$. Já nos debruçaremos sobre este ponto.

Antero fica em estado de vignlia, sem perda total de consciência e a fase agónica é de aproximadamente uma hora. A hemorragia produzida pelas lesð̃es, que se estendiam do palato ósseo, pelos ossos e tecidos moles da cara até ao nariz, vai estar na origem da conclusão médico-legal de morte por asfixia, que Francisco Costa Santos define (Cf. Apêndice). $\mathrm{O}$ tamponamento do orifício de entrada do projéctil e o factode, posteriormente, ter sido deitadoem decúbito dorsal, determina que a hemorragia se desenvolva para as zonas posteriores da cabeça, em direç̧ão ao estômago, à traqueia e aos brônquios. Os espasmos, as contraç̧ð̌es violentas que "dois homens não podiam sustê-lo" $\left({ }^{29}\right)$ tipificam um síndrome asfíxico. Por outro lado, o tempo que medeia entre o disparo e a hora do óbito (morreu perto das 21 horas) confirma a conclusão médico-legal a que acima aludimos.

O estado agónico é progressivamente doloroso e violento. A destruição das mucosas da boca, quer por acção da penetração do projéctil quer pelas graves queimaduras decorrentes da explosão da pólvora negra $\left({ }^{30}\right)$, inibem-lhe os órgãos e a progressão da fase terminal devido à hemorragia não permite aceitar que a gestualidade corresponda

(27) V. Apêndice - Entrevista Francisco Costa Santos.

${ }^{28}$ O problema de Antero ter disparado dois tiros contra si, tem dado origem a múltiplas especulações, havendo, inclusive, quem avente a possibilidade de um terceiro disparo, comoé o caso de Anna Maria Moog Rodrigues que, embora rectifique posteriormente a sua posição, não deixa de escrever "Os poucos transeuntes que passavam pela praça (...) ouviram um tiro logo seguido de outro. Em seguida outro" (in Antero de Quental, Lisboa/S. Paulo, 1990, p. 9).

(29) Apud José Bruno Carrciro, ob. cil., 2.9 vol., p. 289.

$\left.{ }^{(30}\right)$ A pólvora negra produz uma explosão mais lenta do que a pólvora piroxilada (pólvora branca). Tal facto imprime à munição menor velocidade, mas of acho ardente da explosão que salta pela boca da arma é mais prolongado. Em termos balísticos, a pólvora negra determina uma reaç̧ão (o chamado "coice") mais prolongado, ainda que não tão brusco, na empunhadura da arma. Estes esclarccimentos foram prestados pelos peritos de armamento e balística João Figueiredo e Fernando Almeida. 
a uma linguagem, entendida como um acto volitivo consciente. Antero morre asfixiado com o seu próprio sangue, devido a um ferimento que hoje, a medicina, graças ao aparato técnico-científico, poderia resolver, não sendo necessariamente um ferimento mortal.

Em face do que acabamos de escrever, são de excluir os testemunhos romantizados e integrados num quadro da recusa da Morte e perpetuação da imagem da Vida, que nos dão conta de "sorrisos nos lábios", "a suavíssima boca de Apóstolo golfando sangue", "morreu com um sorriso que a todos comoveu a iluminar-lhe o rosto".

No rosto de Antero não podia haver sorrisos nem iluminação. 0 sorriso não poderia ser mais do que um ricto de dor, e a boca, devido à destruição dos tecidos, estaria tumefacta e extraordinariamente vulnerável à dor. Digamos, apenas, que a morte foi tão trágica como terão sido os últimos e insondáveis instantes da sua vida.

Antero de Quental não poderia ter disparado o segundo tiro e, caso o tivesse feito, apenas scria resultado de um automatismo inconsciente decorrente da reacção do sistema simpático $\left({ }^{31}\right)$, ou seja um disparo involuntário, não dirigido contra si, c que se teria perdido nessa noite de Setembro.

Vejamos melhor a questão. Em primeiro lugar, o único depoimento que serve de suporte a este circunstancialismo foi produzido por Mont'Alverne Sequeira e descrito a Bruno Carreiro, trinta e um anos após a morte de Antero. Tal facto permite, desde logo, admitir que existem compreensíveis lapsos de reconstituição no testemunho que aquele biografo reproduz rigorosamentc ${ }^{(32}$ ).

Mont'Alverne Sequeira relata que o encontrou em "decúbito dorsal, afásico [sem fala], fisionomia screna de apóstolo". Pensamos que esta adjectivação é claramente poética e mitificante. Antero tendo a boca gravemente ferida, com o nariz partido e esfacelado, devido à saída da bala, teria de apresentar a cara ensaguentada. As lesões descritas permitem-nos formular algumas reservas que, comoiremos ver, deixam duvidar da "fisionomia screna". Todavia, Mont'Alverne percebe que 0 surto hemorrágico é mais abundante pela boca e "tentei estancar a hemorragia pelos processos ordinários, o que consegui ao fim de alguns minutos". Após esta diligência, nota a insistência da hemorragia

\footnotetext{
$\left({ }^{31}\right)$ V. Apêndice - Entrevista Jorge Costa Santos.

${ }^{32}$ ) Cf. José Bruno Carreiro, ob. cit., 2. ${ }^{9}$ vol., pp. 288-289.
} 
e levanta a hipótese, para um outro médico que, entretanto, chegara, de que poderia tratar-se de um duplo disparo e terá sido Antero que, em linguagem gestual, lhe confirma tratar-se efectivamente, de uma repetição de tiros, erguendo, em dado momento os dedos, médio e indicador da mão direita.

Pensamos que o médico - no contexto mais dramático que qualquer clínico pode viver e que se expressa na confrontação com a morte eminente - sobrevalorizou a gestualidade do moribundo. Na verdade, tal movimento poderia significar dois tiros, ou, como refere Francisco Costa Santos, ser apenas um gesto decorrente de um qualquer reflexo sem significação.

Na verdade, na casuística do suicídio que conhecemos, não são raras as vezes em que, após uma tentativa frustrada, logo se sucede outra que obtém o êxito desejado. Mesmo em disparos dirigidos contra a cabeça, que evidenciam a inequívoca intenção de morrer, existem abundantes exemplos de uma sequência repetitiva até à produção da morte $\left({ }^{33}\right)$. No entanto, não conhecemos qualquer caso em que o indíviduo, depois de desferir um disparo contra o interior da boca, tome a repetir a acção, privilegiando a mesma zona $\left({ }^{34}\right)$.

Por outro lado, não há qualquer testemunho claro de que alguém tivesse ouvido os dois disparos. O já citado Relatório de José Bensaúde indica um polícia "que ouvira confusamente o primeiro" tiro(sublinhado nosso) e mais ninguém informa de que ouviu os dois tiros. Nem Mont'Alverne Sequeira ouviu e, por isso, discutiu o assunto com o colega. Ora, num largo rodeado por paredes altas dos prédios circundantes, no silêncio de uma noite de chuvisco e sem grandes rufdos, as explosð̃es subjacentes às deflagrações dos tiros são notoriamente amplificadas, por motivos de acústica, e, necessariamente, seriam ouvidos pelos residentes nas redondezas, em particular no Hospital que fica bem perto do local. Pensamos, assim, que o segundo tiro é um prognóstico médico e não um facto.

Mais elementos confirmam esta hipótese. José Bensaúde, no mesmo

${ }^{(3)}$ Conhecemos o caso de um indivíduo que disparou três vezes sobre si, dirigindo todos os tiros para a cabeça. Só o último lhe provocou a morte.

$\left({ }^{34}\right)$ Esta informação foi gentilmente confirmada pelo Dr. Jorge Costa Santos que há vários anos se dedica ao estudo médico-psiquiátrico do suicídio e, ainda, pelo agente Samuel Teixeira da Polícia Judiciária, do sector de Homicídios. A ambos agradecemos. 
Relatório afirma curiosamente: "uma bala saiu pela saliĉncia óssea do nariz, ao pé dos olhos, e a outra penetrou pela abóbada palatal no cérebro" $\left.{ }^{35}\right)$. Não diz por onde entrou a primcira c exorbita quando explica onde se alojou a segunda.

Em primciro lugar, nenhum médico, mesmo sendo perito médico-legal, pode afirmar onde a hipotética segunda bala ficou alojada, sem proceder ao exame autóptico da cabeça do cadáver c, como se sabe, Antero não foi autopsiado. Depois, durante a exumação das ossadas, trinta e três anos após a morte, não foi recuperado o projéctil que se teria anichado no crânco. A putrefacção não conduziria à destruição, pelo contrário, pô-la-ia a descoberto. Finalmente é de notar que foi Mont'Alverne Sequeira que procedeu à exumação. É, pelo menos estranha a ausência de curiosidade cientifica para tentar descobrir 0 projéctil que deveria estar entre os restos dos ossos da cabeça. Sabendo-se que os sapatos encontrados no coval foram motivo de exposição na Biblioteca Pública de Ponta Delgada, a bala, para a mentalidade da época, cra, na verdade, uma autêntica relíquia $\left({ }^{36}\right)$.

José Bruno Carreiro recolhe, ainda, um depoimento de Augusto Cabral ( $\left.{ }^{37}\right)$, que pelo realismo e objectividade descrita, é um documento

$\left({ }^{35}\right)$ José Bruno Carreiro, ob. cit., 2.9 vol., p. 288.

${ }^{36}$ ) Consideramos, no mínimo cstranha, esta exumação de Antcro, rcalizada cm Junho de 1924 e cujo auto foi publicado pclo jornal $O$ Correio dos $A$ çores, $n .{ }^{8} 1206$, 29 de Junho de 1924. Não existe qualquer registo nos documentos próprios do Cemitério de S. Joaquim, entre os quais se encontra o que refere a inumação de Antero, estando a coluna que assinala as exumações, sem qualquer indicação. A cscassez de ossos recolhida é pcrturbante. Embora, em 1924, tivesse sido invocada a humidade para explicar a destruição do esqucleto, cxames a que procedemos, respcitantes a outras ossadas de cadáveres inumados na mesma zona do cemitćrio e exumadas muitos anos depois, verificámos que se encontram em bom estado, o que exclue a hipótese da humidade. Esta conclusão foi-nos corroborada pelo cncarregado do cemitćrio José Miguel Sousa Coclho, que trabalha ali, há cerca de quarenta anos e nos informou de várias exum ações em sepulturas com corpos enterrados há muitos anos, cujos csqueletos estão, no essencial, cm bom estado de conservação. Agradecemos a Josć Migucl, assim como à esposa Maria de Fátima Sousa Coclho, a colaboração que nos prestaram, sobretudo, na pesquisa da documentação existente no Cemitério de S. Joaquim.

${ }^{(37}$ ) No Livro de Registo de Doenles de 1891 do Arquivo do Hospital de Ponta Delgada no dia 11 de Setembro de 1891, apenas foi assinalada uma entrada de doentes. Um tal João Leite, soltciro, com a indicação clínica "não se lhe encontrou mollestia". Tambćm não foi referido o óbito de Antcro. Só no dia 1 de Janciro de 1892, o capelão da Santa Casa da Miscricórdia procedeu ao registo em livro próprio (Cf. Bruno Carreiro, ob. cil., $2 .^{9}$ vol., pp. 325-326). 
notável e vale a pena reproduzir, ainda que parcialmente: "A mão direita apoiada no assento do banco; o revólver, com o cano voltado para a parede e talvez uns vinte centímetros longe da mão; a esquerda apoiava-se no braço do banco. A cabeça descoberta... Do nariz (venta esquerda) saía um fio de sangue que se juntava ao que em grande abundância lhe saía pela boca (lado esquerdo), (...) um papel no chão, à esquerda dele, no qual peguei, virei, para ver se havia alguma coisa escrita, mas nada tinha. Conclur pelo amarrotado ser o papel em que ele trouxera o revólver. De pouco a pouco, bamboleava a cabeça para a frente, para trás, para os lados, e assim esteve durante vinte minutos, até chegar a maca em que o meteram, levando-o para o hospital... Enquanto esteve no banco a sofrer horrivelmente, nem um ai saiu daquela boca! A respiração é que era forçada por causa da hemorragia. A cara estava horrivelmente transfigurada, e os olhos meio abertos..."

A primeira conclusão a retirar é que Augusto Cabral encontrou Antero, muito antes de Mont'Alverne Sequeira que já o descreve "em decúbito dorsal". O médico deverá ter chegado numa fase adiantada da agonia (asfixia) do moribundo, (possivelmente os 20 minutos que A. Cabral conta), sendo já muito débeis as reacçð̃es psicomotoras.

Mas é a argúcia e realismo de Augusto Cabral que nos vai permitir a reconstituição do suicídio de Antero, sem grande intervalo de dúvida, à luz dos métodos da actual investigação criminal:

Antero está sentado. Desembrulha o revólver que comprara nessa tarde. É dextro e tal qualidade, leva-o a segurar a arma com a mão direita. Com a mão esquerda separa-lhe o papcl, que deixa cair no chão, sobre esse lado. O revólver, de modelo Lefaucheux é de acção dupla, isto é, basta premir o gatilho para que o percutor, que nestas armas está incrustado no cartucho, actuc sobre o fulminante. Apoia-se com o braço esquerdo no braço do banco e esta posição obriga-o a rodar o corpo ligciramente para a esquerda. Com a mão direita armada, nas circunstâncias já descritas, introduz o cano na boca e dispara. A arma empunhada em posição incorrecta produz o "coice" de reacção ao tiro, saltando por este efeito balístico da boca e "empurrando a mão". O revólver cai no sentido da projeç̧ão do braço, de cima para baixo e ligeiramente da esquerda para a direita, ficando a "uns centímetros longe da mão" que, inerte, repousa sobre o assento do banco. Oimpacto do tiro projecta a cabeça da frente para trás e, devido à posição do corpo, ligciramente da direita para a esquerda. Esta é a razão porque a 
hemorragia é mais abundante pela narina esquerda e, sobretudo, pelo lado esquerdo da boca. A posição $\mathrm{cm}$ que Antero é encontrado (não cai porque o braço esquerdo lhe escora o corpo) determina um fluxo hemorrágico de maior volume, pela boca, graças à acção da gravidade. Não fala - "ncm um ai sai daquela boca" - c devido ao grave ferimento a "cara estava horrivelmente transfigurada". O bambolcio da cabeça corresponde ao cstado de viǵlia e às dificuldades respiratórias (a boca e o nariz cstão destruídos) que indiciam o síndrome asfíxico.

No momento em que é colocado em decúbito dorsal, a hemorragia, já com o palato ósseo tamponado, dirige-se para as zonas posteriores da cabeça, acelerando o processo asfíxico e agónico (Cf. - Entrevista Francisco Costa Santos). O sangue que Mont'Alverne Sequeira vê continuar a sair da boca, depois de suster a hemorragia da cratera existente no palato, não é de um segundo disparo. Resulta do fluxo sanguínco decorrente dos movimentos respiratórios.

Algum tempo depois, Antero de Quental morria asfixiado.

\subsection{Após a Morte}

Antero morreu no Hospital de Ponta Delgada e o acontecimento perturbou o quotidiano daquela instituição. Para além da ausência de documentação sobre o tratamento, o indispensável assento de óbito foi registado três meses depois do evento. Diga-se desde já, que consideramos fundamental csta peça obituária para a comprcensão dos múltiplos processos de apropriação idcológica da obra de Antero e que, em devido tempo, merecerá particular atenção.

O cadáver do pocta-fillósofo não foi autopsiado, motivo no qual radica a auscencia de boa informação sobre as doenças de que se queixava c que o exame do hábito interno do cadáver poderia ter fornecido. Contra tal abstenção se insurgiu João Machado Faria e Maia que redigiu um esboceto de estudo bio-antropométrico do suicidado $\left({ }^{38}\right)$.

\footnotetext{
$\left.{ }^{(38}\right)$ A autópsia cra já, nesta altura, uma prática corrente, sobretudo nas cidades de Coimbra, Lisboa c Porto, onde funcionavam, respectivamente, a Faculdade de Medicina e as Escolas Médico-Cirúrgicas. Qualquer dos médicos de Ponta Delgada, formados naquclas cscolas, tinha conhecimentos suficientes para proceder ao exame tanatológico e extrair conclusõcs, ainda que, por cste tempo a medicina forense fosse bastante incipientc. A "tanatopraxis" cra prática corrente desde a criação do Teatro Anatómico
} 
No dia seguinte realizou-se o funeral para o Cemitério de $S$. Joaquim, em Ponta Delgada, sendo inumado no jazigo de famflia $\left({ }^{39}\right)$. $O$ enterro teve um carácter civil e, à beira da sepultura, discursaram Aristides Moreira da Mota, Júlio da Costa e Pereira de Lacerda $\left({ }^{40}\right)$.

Chegados aqui, continua por responder uma das questões inicialmente colocadas: porque se suicidou Antero de Quental?

Não é possível fazer a resenha exaustiva da série de explicações apresentadas durante estes cem anos. Desde a loucura até à religiosidade mística, encontramos um leque de opiniðes díspares, controversas, algumas despropositadas, que produziram parte significativa da bibliografia sobre Antero.

Não vamos alimentar este caudal especulativo e, nem tão pouco, desde já o confessamos, somos os alquimistas da revelação enigmática.

Este suicídio escapa aos modelos apriorísticos, estabelecidos por quadros epistemológicos diferenciados. Pensamentos, no momento actual do problema, que sóum estudo assente na confluência cpistémica de múltiplas áreas do conhecimento poderá produzir uma aproximação mais rigorosa às condicionantes que o predispuseram ao desejo suicidário. Nesta perspectiva, defendemos o princípio de que cabe ao historiador a tarefa de centrar a questão num contexto globalizante subordinado d̀s relações interdisciplinares para descortinar o eixo, em tomo do qual, se pode prospectivar a história dos acontecimentos que rodearam a morte de Antero de Quental.

por Pombal, nos finais do séc. XVIII (Cf. Miller Guerra, "A Reforma Pombalina dos Estudos Médicos", vol.I, pp. 189-207). Muito embora haja conhecimento de dissecação de cadáveres desde o séc. XVI, porém, é a partir de 1865 com os médicos Manuel Bento Sousa e, posteriormente Miguel Bombarda, Sousa Martins, Curry Cabral, Silva Amado que a Medicina Legal regista assinaláveis progressos com fundamentada scriedade científica. (Cf. a este propósito a pequena mas excelente monografia de Jorge Costa Santos, A Morte e a Morgue, separata da Revista Povos e Culturas, n. ${ }^{2} 3,1988$ ).

$\left.{ }^{(39}\right)$ No Livro de Registo de Títulos de Jazigos do Cemitério Municipal de S. Joaquim d'esta Cidade, $2 .^{2}$ vol., fls. 10 e $10-v$, encontra-se o registo de compra do mausoléu com o título 517, situado no "Quartcl B, Sepultura n. ${ }^{\circ} 2^{\prime \prime}$ em nome de Fernando Quental e datado de 1843.

No registo de imunações ("Maço de 1891 - mez de Setembro", está registada a inumação no "Quartel B, Sepultura 2, no dia 12, Anthero de Quental (Dr)" com a seguinte anotação: "suicidou-se no largo de S. Francisco junto ao muro da Esperança, pelas 8 horas da tarde". Nada consta sobre a sua exumação.

$\left({ }^{40}\right)$ No último capítulo deste trabalho desenvolveremos os aspectos relacionados com o funeral e rituais de evocação. 
Tomando esta premissa, entendemos que será pela penetração na trajectória existencial, procurando captar as continuidades e rupturas, pelas quais se substantiva como homem, que poderemos inteligir do progressivo afunilamento das suas referências vitais até ao momento do suicídio. É, pois, em termos de processo autodestrutivo que vamos abordar os aspectos marcantes do seu percurso biográfico, procurando surpreender as etapas do caminho que percorreu até chegar à última e definitiva visita ao Campo de S. Francisco.

\section{As doenças de Antero}

É extensa a bibliografia que se debruça sobre a doença ou doenças de Antero de Quental e, dos seus sofrimentos, ele próprio, exaustivamente dá conta na sua correspondência particular. Em vez de narrarmos os diversos trabalhos explicativos da sua nosologia, procuremos numa leitura diacrónica aclarar alguns dos mais importantes estudos, verificando os suportes doutrinários e ideológicos onde se sustentaram.

O primeiro grande trabalho médico sobre Antero foi elaborado por um amigo, que também foi seu médico, o Dr. Sousa Martins $\left({ }^{41}\right)$. A análise deste notável clínico que, tal como Antero, após a morte, ascendeu ao panteão da imortalidade, produziu reacções fortíssimas entre os anterianistas mais devotos, não tendo, ainda, terminado o eco desse protesto animoso. Não exageramos se dissermos que a "Nosographia de Antero" continua a sustentar o inacabado debate médico-científico sobre a etiopatogeniae desenvol vimentos sucedâneos em torno da morbosidade de Antero de Quental. Não nos interesssa esse debate matizado de críticas acres, por vezes malévolas, sobre o prognóstico avançado por Sousa Martins. Registemos, apenas, que a "Nosographia" define o suicida como "degenerado", "neurasténico", dominado por múltiplas "fobias", que o autor atribui às condições de morbidez em que Antero foi gerado. Para tanto, levanta problemas de consanguinidade e procede ao cotejo com as doenças típicas em outros dos seus irmãos, para demonstrar que o seu destino só poderia ser a loucura ou a genialidade (entendida como uma degenerescência)

(41) Idem, "Nosographia de Anthero de Quental", Anthero de Quental - In Memoriam, pp. 219-313. 
decorrente dos hipotéticos problemas de consanguinidade hereditária.

Apesar das críticas pertinentes que são formuladas ao discurso clínico de Sousa Martins $\left({ }^{42}\right)$, onde trespassa algum "exibicionismo fabulador", não podemos esquecer que conhecia Antero, estimavam-se, e admitimos que só a verdadeira admiração e respeito que este lhe merecia, levou aquele notável médico a enveredar por uma abordagem de raiz psicopatológica, bem longe da sua especialidade médica. Com uma formação cientifica de raiz positivista, companheiro de Curry Cabral, Miguel Bombarda, Manuel Bento Sousa, empenhado em campanhas higienistas, desempenhando destacada acção no combate à tuberculose e outras doenças epidémicas, ver-se-á que a azáfama neste campo de acção não o predispunha ao acrescentamentopsiquiátrico que, anos antes, o também célebre e controverso Charcot introduzira na área da ciência médica.

Espaçadamente têm surgido propostas para a reavaliação da "Nosographia". No centenário do nascimento de Sousa Martins, na alocução proferida, Diogo Furtado, insurgindo-se contra a exacerbação crítica àquele estudo, propõe o reexame já que o considera, no essencial, ainda actualizado $\left({ }^{43}\right)$.

Em 1963, o neurologista Miller Gucrra $\left({ }^{44}\right)$, de formação católica e ncuropsiquátrica, escreve o trabalho apaziguador sobre as doenças de Antero, definindo-lhe uma "psicose neuro-depressiva", desvalorizando o carácter fóbico que Sousa Martins relevara e escandalizara os anterianistas católicos.

Mas o estudo de Miller Guerra, ainda que tenha contribuído para um conhecimento mais rigoroso da etiopatogenia de Antero, não esgotou

${ }^{(42}$ Cf. Apêndice - Entrevista Jorge Costa Santos.

(43) "A defesa do ponto de vista de Sousa Martins está por fazer: a sua tese da anormalidade psíquica de Antero, a única aceitável aos olhos de um especialista de hoje, de rebatida que tem sido, parece enterrada nas brumas do esquecimento" (Cf. Diogo Furtado, "O centenário de Sousa Martins", Revista de Imprensa Médica, Ano IX, n. 7,10 de Abril de 1943, p. 126).

$\left.{ }^{(44}\right)$ É nos finais dos anos 50 , inícios dos anos 60 que a ruptura epistemológica entre a neurologia e a psiquiatria tem lugar. Miller Guerra, actualmente professor jubilado, afirma-se como neurologista, ainda que de formação neuropsiquiátrica. Em 1963 publica a Patografia de Antero de Quental, separata da Revista Rumo de Fevereiro do mesmo ano. A formação católica do autor não é estranha a este estudo que, como vercmos, é fundamental para a recuperação católica de Antero. Registe-se, ainda, o facto da Revista Rumo defender as posições conotadas com a Opus Dei. 
o tema. Em 1989, Maria Manuela Brazette $\left({ }^{45}\right)$, revalorizando alguns dos postulados defendidos por Sousa Martins e, tal como este, referenciando a análise do doente através da sua poética e biografia, afirma: "Não é por acaso que os dois filhos de Fernando e Ana Guilhermina adocceram com depressões; a de André, muito provavelmente psicótica; a de Antero, talvez uma depressão limite; porque nunca há traços psicóticos ao longo da sua vida, não há altemância de fases maniformes, ou mesmo hipomaníacas, e depressivas; há antes um estado depressivo crónico, com ligciras flutuaçðes..."

Finalmente, em 1991, Costa Santos $\left({ }^{46}\right)$ considera cxistirem fortes probabilidades de Antero ter sofrido de um Distúrbio Afectivo Ciclotímico $\left.{ }^{(47}\right)$.

${ }^{45}$ ) Cf. M. Manuela Brazette, "Viver na Esperança - Perder a Esperança" in Estados-Limites,IVSeminário de Psicologiae Psicopatologia Clínica, Lisboa, Hospital Miguel Bombarda, 1989, pp. 23-35.

${ }^{46}$ ) Cf. Apêndice - Entrevista Jorge Costa Santos.

$\left({ }^{47}\right)$ Confrontámos a opinião deste investigador e a hipótese de um Distúrbio Ciclotímico com o "diagnóstico diferencial de Distúrbio Ciclotímico in DSM III, Manual de Diagnóstico e Estatística dos Distúrbios Mentais, Lisboa, Ed. Portugucsa de Livros Técnicos, 1986, pp. 211-212.

Apresenta duas sérics de sintomas, para os periodos depressivo e hipomaníaco, respectivamente que pela identificação conotativa com as atitudes comportamentais de Antero, vale a pena transcrevcr: "Durante os períodos depressivos existe um humor depressivo, ou perdas de intercsse ou prazer em todas, ou quase todas as actividades ou passatempos habituais, c, pelo menos três das seguintes características: 1) insónia ou hipersónia; 2) baixa de energia ou fadiga crónica; 3) sentimentos de inadequação; 4) diminuição de eficácia ou rendimento escolar, profissional ou domćstico; 5) diminuição da atenção, da concentração ou da capacidade de pensar com clareza; 6) evitamento social; 7) perda de interessc ou prazer sexual; 8) reduçãona participação em actividades agradáveis, culpabilidade por actividades passadas; 9) sentimento de identificação; 10) menos falador do que o habitual; 11) atitude pessimista quanto ao futuro ou de lamentação àcerca de eventos passados; 12) criscs de lágrimas ou choro;

Durante os períodos hipomaníacos existe um humor exaltado, expansivo ou irritável e, pclo menos, três das seguintes características: 1) diminuição da necessidade de dormir; 2) mais energia do que o usual; 3) sobrevalorização da auto-estima; 4) aumento da produtividade, frequentementc associada a hor as pouco usuais de trabalho que o indivíduo impõe a si próprio; 5) acuidade e actividade do pensamento; 6) procura incessante de companhia; 7) hipersexualidade sem consciência das eventuais consequências nefastas; 8) participação excessiva em actividades agradávcis, com negligîncia do alto risco de consequências nefastas;9) agitação física; 10) mais falador do que o habitual; 11) optimismo excessivo ou exacerbação de feitos passados; 12) riscos, graccjos ou trocadilhos despropositados. 
Por outro lado, no que respeita a doenças de raiz somática, as queixas que apresenta, ao longo de toda a vida, de problemas de estômago, de dificuldades digestivas que tanto o atormentavam, levam o médico Raúl Bensaúde, filho de José Bensaúde, a diagnosticar-lhe retrospectivamente, como muito provável, uma "estenose do piloro" $\left({ }^{48}\right)$.

Neste momento, fiquemo-nos apenas pela importância do contributo médico para nos colocarmos mais próximos do enigma que levou Antero ao suić́dio, embora nos pareça insuficiente esta univocidade "doença-suicidio". Com Edgar Morin ( $\left.{ }^{49}\right)$ partilhamos a ideia de que 0 processo vital é, em si, também um processo de morte, assentes numa aç̧ão dinâmica, imbricados, e prospectivando as atitudes do homem, no conflito entre a inevitabilidade da morte e o desejo da amortalidade. Caminhando por esta matriz, verificaremos que a trajectória existencial de Antero de Quental nos obriga a caminhar para a pesquisa mais alargada, onde seja possível decifrar comportamentos de etiologia suicidária que não se restrinjam à mera morte biológica.

Perscrutando a evolução da vida de Antero e tendo, principalmente, como mais sólido apoio as Cartas, onde pelo carácter intimista e confessional, mais se expð̃e, concatenando-as com a sua actividade pública, somos forçados a concluir que o tiro que desferiu, foi apenas, a última das muitas amputações que voluntariamente realizou contra si, ao longo da vida. Estamos perante um suicídio construído em processo, através de auto-mutilações sucessivas. É um suicídio a longo prazo que se percebe em cada momento decisivo da vida do cidadão Antero de Quental, em que a noite de 11 de Setembro de 1891 foi apenas, um mero ponto final.

\section{Um suicídio feito de muitos suicidios}

\section{1. Da recusa do suicídio à aceitaçāo da morte}

A maioria dos trabalhos centrados na explicação do suicídio de Antero de Quental associa-o, sem qualquer pudor, à atitude do poeta-

$\left.{ }^{(48}\right)$ José Bruno Carrciro, ob. cit., $2 .^{9}$ vol., p. 44 . A este propósito v. Apêndice - Entrevista Francisco Costa Santos.

(49) Edgar Morin, O Homeme a Morte, Ed. Europa América, s.d. 
-filósofo perante a morte $\left({ }^{50}\right)$. Pensamos que não é paćfica esta identificação, já que o acto não pressupõe a necessidade de uma interpretação filosofica. Para Antero $\left({ }^{51}\right)$, a morte é uma ideia que constitui "a base da vida", incorporando uma "razão metafísica" que a torna necessária na caminhada para o Optimismo Transcendental. A imortalidade física conduziria à imoralidade e só a consciência da finitude biológica permite ao homem superar-se, procurando viver de acordo com a inevitável escatologia metafísica da sua existência. Tal comportamento implica a aceitação racional da morte como uma necessidade física intrínseca à "necessidade metafísica". Esta abordagem ontica do processo evolutivo e transcendental da vida, leva Antero à seguinte conclusão: "Saibamos compreender a Morte, que é a única maneira de sabermos comprehender a Vida e de sabermos viver" $\left.{ }^{52}\right)$. A base dialéctica desta "metafísica indutiva" coloca o problema da Morte, no interior da trajectória evolucionista da existência, como 0 momento da superação da Vida "física" à Vida "meta-física", pelo que a aceitação da finitude temporal deve ser entendido como um momento sublime da evolução. Percebe-se, assim, que entende a Morte como um tropismo da existência (atraç̧ão-rcpulsão), dadoo caráctcr imanentista da vida espiritual. Cremos que é no interior desta textura gnosiológica que devemos encarar os Sonetos, sendo de colocar muitas reservas às tramas teoréticas que deles têm partido para concluir da inevitabilidade do suić́dio. Reforça esta atitude o facto de Antero ter escrito os seus últimos poemas em 1885, portanto scis anos antes da morte. De facto, em carta de Junho desse ano, ao amigo António de Azevedo Castelo Branco $\left({ }^{53}\right)$, afirma: "(...) a propósito de versos, dir-te-ei que já não os faço. Secou-se-me a fonte viva: c como depois de ter sido poeta, não quero continuar versificador, parei. Como despedida, vou im-

${ }^{\text {so }}$ A começar por Sousa Martins, vários autores têm procurado captar a predisposição suicidária de Antcro, através da análise enfatizada dos seus Sonetos sobre a Morte.

$\left.{ }^{(51}\right)$ Antcro de Quental, "Philosofia da Morte e a Metaphisica da Morte", apud Archivo dos Açores, XII vol., p. 195.

${ }^{52}$ ) Ibidem. Sobre esta temática veja-se o notável ensaio de Fernando Catroga, "A Metafísica Indutiva de Antero de Quental", Biblos, Vol. LXI, Coimbra, 1985, pp. 472 $-507$.

${ }^{(53)}$ Cartas I, ob. cit., c. 461, a A. A. Castclo Branco, 6 de Junho de 1885, pp. 741-742 . 
primir a colecção dos meus Sonetos (...)" $\left({ }^{54}\right)$.

Não se lhe conhece, desde então, qualquer poema. No entanto, é muito anterior à elaboração poética dos Sonetos, esta relação de conformismo e aceitação da Morte, mesmo no seu período mais "apolíneo", em 1866, quando ao mesmo amigo, escreve ( $\left.{ }^{55}\right)$ : "(...) A natureza é em mim conservadora: só o espírito é revolucionário (...) Mas a vida é um silogismo (...) a conclusão é a morte na doçura da própria consciência e na fraternidade das outras consciências que lhe aprovam a vida".

A partir de 1874, após o agravamento do estado de saúde, sentindo dores físicas terriveis na coluna vertebral, praticamente entrevado, quase impossibilitado de andar e de escrever, a atitude perante a Morte é, nos seus principais contornos, aquela que lhe captámos dez anos antes - conformismo e plácida aceitação do fim da vida: $\left({ }^{56}\right)$ "Que se pode esperar dum verdadeiro entrevado, que não anda, e quase não dorme, ncm come, num cstado de fraqueza que até para escrever uma carta precisa dum esforço grandíssimo? (...) Assim vivo há meses, meu caro amigo, e assim cuido acabar". Ao longo do espistolário, que tcrmina cm finais de Agosto de 1891, percebe-se um progressivo e cada vez mais esclarecido diálogo intimista com a problemática da Morte, diálogo místico e filosófico, naturalmente enriquecido pelo seu amadurecimento espiritual. "Se a doença foi ocasião para reflectir com mais madureza no símbolo misterioso que é a Morte, é isso muito natural, porque $\mathrm{cm}$ tal estado a Morte apresenta-se ao nosso pensamento com mais insistência ou mais autoridade: mas dessas reflexð̃es conclú coisas que nada têm de tristes, antes são muito confortáveis, uma espécie de filosofia idealista da Morte" $\left({ }^{57}\right)$.

Quer os Sonetos quer a trajectória de raiz̨ metafísica do discurso filosófico anteriano, concorrendo com a intervenção confessional das Cartas, que nos dão preciosas indicações sobre o seu estado psicossomático, não nos entreabem a fresta pela qual poderemos perceber a inevitabilidade do suicídio.

$\left({ }^{54}\right)$ A publicação a que se refere é Sonetos Completos, publicados por J. P. Oliveira Martins, Porto, Liv. Portucnse de Lopes e C.', Editores, 1886.

(55) Carlas I, ob. cit., a Vicente Machado Faria c Maia, Dezembro de 1861, p. 20.

( $\left.{ }^{56}\right)$ Ibidem, c. 123, a Jaime Batalha Reis, Março de 1874, p. 233.

$\left.{ }^{(57}\right)$ Ibidem, c. 150, a A. A. de Castclo Branco, Março/Abril de 1875, p. 277. 
Por outras palavras, a aceitação da ideia de Morte, quanto a nós, não é condição nem necessária nem suficiente para daí se extrair a conclusão de que a autodeterminação da sua própria morte, teria de ser o corolário lógico e coerente do percurso existencial de Antero.

Aliás, desde muito cedo repele a ideia do suicídio $\left({ }^{58}\right)$. A educação, particularmente da infância, dirigida pela mãe, enformada por um rígido padrão religioso; o conjunto de sonhos e projectos que se sucederam durante toda a vida, que logo se desmoronavam uns, renasciam outros; a profunda sinceridade e generosidade da sua "praxis" política e social, a dramática confrontação com a doença e, sobretudo, o desejo apaixonado de construção do seu sistema filosófico aproximavam-no da compreensão metafísica e mística da Morte, como um instante redutor e, simultaneamente transcendental da tangibilidade do Bem Universal, mas afastavam-no do suicídio: "Se eu não fosse místico, já me tinha deitado a afogar, palavra de honra: verdade é que se não fosse místico também não sentia esse insaciável desejo e esse desespero; engolia gulosamente a broa áspera das minhas abstracções como se fosse toucinho do céu" $\left.{ }^{59}\right)$.

Nesta linha discursiva, poder-se-á concluir que o "espírito revolucionário" que o leva a problematizar a Morte em termos filosóficos, tornava-se, no imbricado com o misticismo, no reforço do desejo de querer viver. Acrescente-se que o misticismo de Antero, ainda que formalmente tenha mudado de tonalidade, desde o perfil desenhado pela escatologia de raiz católica, onde se formou e o levou a admitir a hipótese de ser Padre, passando pela pesquisa do Nada, até ao pampsiquismo de identificação com a espiritualidade cristã de $S$. Franciscod'Assis, éum traço marcante edefinitivo da sua personalidade. O Santo Antero $\left({ }^{60}\right)$, como the chamavam os amigos íntimos, es

$\left({ }^{58}\right)$ Ao longo de todo o epistolário de Antero, nas várias vezes que se refere an suicídio é sempre numa atitude de recusa. A morte que espera, e várias vezes anuncia. é a morte natural, nos primeiros tempos como consequência da doença e, mais tarde. associando-a à velhice.

$\left({ }^{59}\right)$ Cartas I, ob. cit., c. 121, a Oliveira Martins, 26 de Novembro de 1873, p. 225.

$\left({ }^{60}\right)$ Eça de Queirós consagrou definitivamente a "canonização" de Antero com o seu emocionante trabalho "I/m Génio que era um Santo", Anthero de Quental - In Memoricum, pp. 418-522. Porém, Guerra Junqueiro evoca-o, na mesma obra, sob o título "O Drama da Sua Vida", definindo-o como "um santo, um filósofo e um heroe" (p. 473) e, finalmente, Lobo de Moura também o recorda como "santo" (p. 139). 
conotativo dessa atitude mística de identificação com a Verdade, isto é, "a cidade dos pensamentos" como ele lhe chamava e coincidente com a ideia de Espírito Universal de elaboração hegeliana. "Um santo leigo, desligado da doutrina cristã; mas sempre obediente à ideia do bem" $\left({ }^{61}\right)$.

Durante toda a vida, e salvo momentos de maior depressão que adiante analisaremos, não se encontra substantivamente documentada qualquer iniciativa de Antero que permita concluir da predisposição, ainda que pontual, para cometer o suicídio. Pelo contrário! Por diversas vezes se distancia dessa opção, quando amigos íntimos, inquietos pela postura pessimista conjugada com a depressão psicopatológica, o confrontam com tal ideia $\left({ }^{62}\right)$ : "V. parece julgar que eu esteja disposto a suicidar-me, duma maneira por assim dizer negativa, isto e, deixar-me morrer placidamente mas sem luta, sem fazer da minha parte - e prova-me que isto é ainda suicídio, e por conseguinte ímpio. Estou disposto a seguir tudo o que for necessário para não parecer que me quero suicidar..."

Pessimista, na linha de Schopenhauer e próximo de Hartmann, tem a conviç̧ão de que a Morte seria um meio de libertação se, por ela, o Homem caminhasse para o "optimismo transcendente". No cumprimento do acto de viver essa caminhada criaria o sentimento de renúnciae de libertação pós-Morte, traduzindo a construção deste sentimento 0 verdadeiro gozo da existência $\left({ }^{63}\right)$. Esta conduta, proposta por Antero, partindo do pessimismo e assim recusar o suicídio, para justificar a necessidade de viver, é de 1889, ou seja dois anos antes de

\footnotetext{
Segundo José Bruno Carreiro, terá sido a esposa de Lobo de Moura, chamada Maria Ermelinda que, assim, o terá baptizado pela bondade e ternura com que Antero tratava as filhas do casal (Subsídios... p. 104). Francisco Maria Supico no elogio fúnebre de Antero, na Junta Geral do Distrito de P. Delgada, evoca-o como "santo", já numa perspectiva mitificante da sua imortalidade.

${ }^{(61)}$ Cf. João Lobo de Moura, "O Fim do Poeta", Anthero de Quental - In Memoriam, p. 139.

${ }^{(62}$ Cartas I, ob. cit., a Jaime Batalha Reis, 5 de Maio de 1874, p. 239.

$\left({ }^{63}\right)$ A propósito do caso Chambidge, que apaixonou a opinião pública, tendo ocorrido um homícidio e um suicídio, numa posição claramente crítica aos eventos, escreve: "O pessimismo só seria salvador se fosse (isto é, se pudesse ser) completo, caminhando-se através dele para uma espécie de optimismo transcendente, para a serenidade na perfeita conviç̧ão da insuficiência da vida fenomenal, e pondo-se o verdadeiro gozo da existência nessa mesma convicção e nesse mesmo sentimento de voluntária renúncia" (Cf. Cartas II, ob. cit., c. 620, a Oliveira Martins, 30 de Novembro de 1890,.p. 970).
} 
morrer. Merece, pois, algumas considerações, a informação até nós chegada, das várias tentativas de suić́dio que Antero terá realizado e que têm sido utilizadas para, precipitadamentc, mostrar que ele era um suicida potencial.

São três ao todo. A primeira terá sido em Paris, no ano de 1866, a scgunda em Ponta Delgada em 1874, quando se manifesta a docnça, a terceira em casa de Oliveira Martins, depois de ter regressado de Paris, onde consultara Charcot e se apaixonara por uma companheira de doença e que estaria na origem da decisão de pôr termo à vida.

Em finais de 1868, Antero de Quental chega a Paris, à procura do baptismo proletário e desejoso de expcrimentar o sentimento de fraternidade revolucionária, enquanto sedimento da classe explorada. A natural instabilidade, acrescida da ansiedade temperamental, amplificam o choque que o revolucionário das Odes Modernas reccbe ao ser confrontado com a realidade cruel $\mathrm{c}$ desumana $\mathrm{cm}$ que se traduzia 0 quotidiano do proletariado parisiensc. O revolucionário romântico que se autoconstruf́ra a partir da idealização da esperança libertadora não aguenta o embate e, semanas depois, quer regressar. Desse amargo impacto reccbido à chegada, dá conta em duas cartas cnviadas a António Azevedo de Castelo Branco $\left({ }^{64}\right)$ e a Alberto Sampaio $\left({ }^{65}\right)$.

Sobretudo a segunda carta é esclarecedora do estado de espírito de Antero. Torturado pela solidão, desiludido pela Paris real, tão longe da Paris prolctária e revolucionária que idealizara e, ainda, atormentado pela má consciência da "picdosa mentira" que forjara para justificara partida (Antcro comunicara à família que ia trabalhar como jornalista), pede a Alberto Sampaio que o receba de volta $\left({ }^{66}\right)$.

É esta carta que leva Albcrto Sampaio, quando escreve no In Memoriam (p. 16) a levantar a hipótese de ter sido Antero tentado ao suicídio, c, também, condu\% António José Saraiva, a imputar-lhe "pensamentos suicidas" $\left({ }^{67}\right)$.

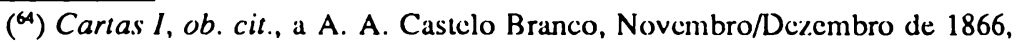
p. 84.

${ }^{65}$ Ibidem, c. 45, a Alberto Sampaio, fins de Dezembro de 1866, p. 85.

${ }^{(66)}$ António José Saraiva fixa o Inverno de 1867 para a chegada de Antero a Paris. É uma imprecisão, pois, por esse tempo já se encontrava, de novo, en Ponta Delgada. (Cf. A Tertúlia Ocidental, Lisboa, Gradiva, 1990).

$\left({ }^{67}\right)$ Cf. ob. cit. nota supra, p. 26. 
Mas examinemos a carta, para avaliar se, de facto, Antero se predispóe ao suicídio ou se teve pensamentos suicidas, isto é, se organizou mentalmente o propósito de se suicidar. Depois de dar conta da profunda tristeza que sentia, pelas razőes já referidas, dèscreve a confrontação com a natureza do trabalho operário. Num país aceleradamente industrializado, em que as relaçðes sociais de produção decorrentes desta fase da expansão capitalista assentam na exploração desumana e brutal da mão de obra produtiva, Antero ganha consciência de que o conceito de Trabalho, sedimentado na fratemidade operária e, por via disto, potencialmente libertador, é um ilusório fogo fátuo. Em Paris, o "trabalho é triste como todo o trabalho moderno, forçado, partido, dividido, desnatural e injusto", confessa.

Esta decepção é compreensível. Antero não saíra, até então, de Portugal para qualquer das potências industrializadas - Inglaterra, França, Alemanha. Como refere Eça no seu trabalho "O Francesismo" e para esta circunstância especiffica, em "Um Génio Que Era Um Santo", o conhecimento dessas realidades era feita por Antero e seus companheiros de Coimbra, através dos pacotes de livros que, pelo caminho de ferro, dali chegavam ao Portugal arcaizante e pre-industrial, e pela leitura dos quais idealizara uma imagem romântica e generosa da Revolução. É assim, que já experimentado na dura realidade parisiense, pode afirmar a Eduardo de Almeida Andrade $\left({ }^{68}\right)$ : "não exagero afirmando que cinco meses em Paris valem mais do que os cinco anos de formatura em Coimbra, para a verdadeira instrução e iniciação na verdadeira e soberana ciência da realidade humana".

Essa "formatura" de cinco meses relevara em Antero o que de mais "noctumo" em si existia, usando a terminologia sergiana. No entanto, não o conduziu a pensamentos suicidas. Na carta a Alberto Sampaio, a que temos vindo a fazer referência, afirma claramente que quer regressar a Portugal, para se esconder na quinta que o amigo possura nos arredores de Guimarães, porque não quer que a família saiba da sua condição de tipógrafo - "picdosa e não desonesta mentira", como ele proprio a sente. É neste contexto que afirma $\left({ }^{69}\right)$ : "Prefiro, porém, deitar-me ao Sena a aparecer à faḿlia - os mais são-me indiferentes

${ }^{(68)}$ Cartas I, ob. cit., c. 46, a Eduardo de Almeida Andrade, 18 de Julho de 1867, p. 88.

$\left.{ }^{(69}\right)$ Ibidem, c. 45, a Alberto Sampaio, fins de Dezembro de 1866, p. 86. 
- depois de a ter embalado na persuasão de que tinha aqui um óptimo emprego".

Ora é necessário que sejamos prudentes. No contexto da afirmação, o tal mergulho no Sena é um desabafo que pouco ou nada tem de intenção. A predisposição para o acto suicidário exige manifestações preparatórias da construção do desejo suicida, que não se podem inferir daquela expressão. A nosso ver, não passa, ontem como hoje, de um desabafo comum a qualquer mortal. Conscientemente Antero prepara sim, o regresso a Portugal, trespassado pela ansicdade e angústia da solidão c desilusão c, por isso, quer fugir. Aliás, pouco tempo depois está na quinta de Sampaio.

No entanto, é curiosa esta expressão em que conexiona a morte auto-determinada com o afogamento. Refere-o aqui, depois em 1873 a Olivcira Martins e, finalmente, poucos dias antes de morrer, torna a falar no mergulho no mar "com uma pedra atada ao pescoço".

Esta idealização do suicídio, agora que é conhecida a história postcrior, mais reforça a ideia de que cle não pensou cm suicidar-se, mas que as palavras foram além daquilo que cram os scus verdadeiros desígnios. O tempo haveria de mostrar que a lógica c os métodos utilizados scriam bem diferentes.

Oliveira Martins $\left({ }^{70}\right)$, por seu turno, reclama que pelo menos duas vezes afastou de Antcro a decisão suicida. Afirma até, que de uma delas o chegou "a desarmar". Comecemos por csta, ainda que seja a última das três que mencionámos.

A primeira questão que tal asscrção levanta é a scguinte: que arma empunhava para determinar a sua morte? Olivcira Martins não nos dá esta informação. No entanto, é legítimo duvidar de que estivesse empunhando uma pistola ou um revólver. Alice Moderno, no trabalho que publicou no In Memoriam $\left({ }^{71}\right)$, reproduz uma carta onde reconstrói factualmente os últimos momentos antes do suicídio $\mathrm{cm} 1891$, sendo inequívoco o testemunho recolhido pelo empregado da loja onde Antero vai comprar o revólver. Afirma ele que "nunca pegara numa arma de fogo" c é o próprio vendedor que lhe explica como funciona

$\left({ }^{\circ}\right)$ Correspondência de J.P. Oliveira Martins, cditada por Francisco de Assis Oliveira Martins, Lisboa, Parceria António Maria Percira, 1926, p. 160.

('1) Ob. cil., pp. 204-205. 
e carrega a arma.

Não cremos que Anteroprocurasse iludir o seu interlocutor, criando-lhe a ideia de uma falsa ignorância sobre o manuseamento de uma arma de fogo. A respeitabilidade com que é tratado, a justificação que apresenta - vai "residir para um sítio retirado da vizinhança" -, o seu prestŕgio em S. Migucl, são boas razões para a compra da arma sem criar suspcitas de segundas intenções. Não mentia. De facto não sabia mexer em armas de fogo.

Sendo assim, a que braço armado se refere Oliveira Martins? Não é crível que se tratasse de um sabre, arma com que se bateu com Ramalho Ortigão em 1865, na refrega da Questão Coimbrã. Embora Jaime Batalha Reis, no testemunho que deixou no In Memoriam $\left({ }^{2}\right)$, recorde lutas entre os dois, com sabres de pau, a familiaridade com este tipo de arma não era grande, nem consta que Antero possuísse algum sabre. Oúnico objectoque usava, que podia funcionar comoinstrumento contundente, mas inócuo para a realização de um suicídio, era uma bengala que Eça de Queirós lhe oferecera nos tempos de Lisboa.

O problema subsiste: que arma? Aproximemo-nos desta questão por outro lado. Oliveira Martins, na casa do qual estava hospedado Antero, depois da desilusão amorosa de Bellevue, tcm pelo amigo uma afeição que vai além da amizade. Para o autor do Portugal Contemporâneo, Antero funcionava como o seu alter-ego, constituindo o seu referencial crítico privilcgiado. Ao longo da intensa correspondência trocada entre ambos, principalmente na fase inicial, é Antero que critica, corrige, dá pistas de investigação ao activo e incansável amigo, tornando-se no autêntico burilador do génio martiniano. Por sua vez, Oliveira Martins representava para ele o modelo de acção que tanto o fascinava e da qual se demitira. Este encantamento fraternal entre os dois homens, conhecidas as fragilidades de um e a pujança activa do outro, leva Martins a manter uma atitude de pater, em constante preocupação com a instabilidade do seu grande amigo e, por isso, tendendo a exacerbar sintomas e emoções, colocando-as na limiaridade de dramáticas e radicais soluçð̃es.

Por outro lado, o discurso literário de Oliveira Martins recorre, às vezes com exagero, à metáfora cà imagética que é perceptível em todos os seus trabalhos.

('2) Ibidem, p. 446 
Atacando o problema por este ângulo, fica-nos a forte possibilidade de Martins ter "desarmado a presunção" de que Antero, revolvido em múltiplas inquietaçð̃es se encaminhava para o suicídio: inquietaçõcs empoladas por paternalistas razões emocionais e afectivas. E é Antero de Quental que em carta de $1881\left({ }^{73}\right)$, nos retira qualquer dúvida àcerca do que acabamos de expôr: "Eu nunca me aborreci em sua casa e em sua companhia. V. esquece que, da última vez que af estive de longada, me agitavam os tormentos duma situação de sentimento singular e onde tudo parecia feito para me pungir. Eu sofria tanto que andava estonteado. Mas não me aborrecia, e certo que se estivesse noutra parte ainda o sofrimento me pungiria mais".

Também na segunda tentativa, datada de 1874 , estamos $\mathrm{cm}$ crer que a situação foi empolada. Nesse ano, Oliveira Martins corre a S. Miguel para visitar Antero, empolou o desespero e a ansiedade doentia do amigo (nesta altura confrontado com a impossibilidade em terminaro Programa de Trabalhos) e sobrepreocupado com a doença dele, crê descortinar nas suas palavras uma intenção objectiva de procurar a morte. Mas, ainda tornando à pretensa tentativa de suicídio no Porto, Martins sobrevalorizava a dor de Qucntal. E sobrevalorizou-a ao ponto de esquecer a nobreza de carácter do amigo. Este, jamais se suicidaria em casa do seu hospedeiro por respeito a família que o acolhia. A vida e a morte vieram confirmar esta asserção. A 11 de Setembro, hospedado na casa de José Bensaúde, saiu e foi pôr termo à vida na intimidade da noite do Campo de S. Francisco.

Finalmente, no que respeita à segunda tentativa que tcria ocorrido em Ponta Delgada, nos princípios de 1874, quando a doença se evidencia em toda a plenitude e recebe a visita acima citada, de Oliveira Martins, é o próprio Antero que desfaz o equívoco que o tom pessimista das suas cartas criara cntre os amigos que de longc o acompanhavam. Em carta a Jaime Batalha Reis, datada desse tempo, afasta definitivamente a hipótesc do suicídio, ainda que se trate de "um suicídio por omissão" (Cf. nota 100).

A recusa sistemática do suicídio $\mathrm{c}$ a accitação de uma morte breve e repetidamente invocada são, como vimos, dois pólos distintos de um mesmo problema que é a complexa personalidade anteriana. O deslizar

$\left({ }^{73}\right)$ Cartas I, ob. cit., c. 338, a Oliveira Martins, Maio de 1881, p. 558. 
para a morte é captado no processo tumultuoso em que interiormente o Antero-Homem vive constantemente.

Mas esta assunção racional da recusa da auto-determinação da própria morte não vai resistir, com o envelhecimento e o desenvolvimento da patogenia plural, alimentada pela ausência de prevençð̃es terapêticas e multiplicada pela instabilidade afectiva e emocional, e Antero caminha inadvertidamente para a destruição irreversível, definitivamente consumada em 11 de Setembro de 1891.

\subsection{O caminho para o suicídio}

No quadro actual do conhecimento científico, Antero de Quental pode ser integrado num grupo suicidário de alto risco. No entanto, $\mathrm{e}$ como vimos, não encontramos indicadores que nos permitam intuir da organização comportamental de suas atitudes em direç̧ão decisiva e premeditada, com vista à auto-destruição física $\left({ }^{4}\right)$. A morte, despida da elocubração metafísica, aparece-lhe sempre como um momento do ciclo biológico, natural e ausente de dramatismo. Várias vezes refere tal conviç̧ão, de que se aproxima a velhice e a velhice é o prenúncio do fim da vida biologicamente organizada. A morte que espera e deseja é, desta forma, a morte natural e é através da objectivação desta realidade que constrói o discurso metafísico da existência. Basta a leitura de algumas cartas, o conjunto de Sonetos sobre a morte e os textos filosoficos que escreveu, para se perceber que a procura brusca do fim da vida está ausente do seu discurso ontológico.

Veremos, pois, como no nosso entender, o suicídio se torna a única solução para Antero, mobilizando em favor da nossa tese os atributos da sua personalidade e da actividade que desenvolve, que truncaram aspectos essenciais para o seu equilíbrio psicossomático.

É difícil de perceber, julgamos que até impossível, o momento em que se começa a desenhar no comportamento de Antero uma trajectória que inexoravelmente o vai conduzir à ausência de soluçð̃es, abrindo-

( $\left.{ }^{4}\right)$ Significa isto, que apesar de lhe reconhecermos comportamentos auto-destrutivos não os consideramos suportados pela intencionalidade, mas ditados pela estrutura do scu temperamento, isto é condicionados pela doença psíquica de que sofre. 
-lhe o caminho para o suicídio $\left({ }^{75}\right)$.

António Sérgio vê em Antero, dois Anteros $\left(^{76}\right)$. O primeiro corresponde a um período que vai sensivelmente de 1863 a 1875 , dominado por uma tendência "apolínea" ou "diurna", que contrasta com o outro Antero "romântico" ou "nocturno", que coexistindo conflitualmente com o primciro, o ultrapassa em termos cronologicos. O ensaísta levanta, assim, uma questão fundamental. Se atentarmos no pcrcurso público, nas alcgrias, nas dores confessadas aos amigos, verificar-se-á a coexistência "apolínea" e "romântica" de um homem tempcramentalmente apaixonado, cuja sensibilidade lhe provoca efeitos hiperb6licos, quer pelo afundamento desesperante, e desta forma a depressão cresce e agrava-se, quer na acção apaixonada substantivada na intervenção política, social e literária, vivendo em constante convulsão "browniana" no interior dos seus "distúrbios afectivos".

Denota-se uma quase permanente ansiedade mórbida $\left({ }^{77}\right)$, nos gestos e actos. Esta atitude psicológica, traduzida no sem número de queixas que deixa ao longo de praticamente toda a epistolografia confessional, assenta no sofrimento de dores musculares, de dores de

${ }^{(75)}$ Muitos autores têm procurado fixar o momento em que Antero de Quental se decide pelo suicídio. Não é fácil a resposta a um tal quesito. José Bruno Carreiro põe em realce os últimos momentos vividos $\mathrm{em}$ Ponta Delgada. Por outro lado, Hernâni Cidade no seu cstudo Antero de Quental, Lisboa, Ed. Presença, 1988, 2." ed., coloca o início dos preparativos do suicídio em 1890, exactamente um ano antes da morte, quando realiza o testamento $\mathrm{cm}$ Vila do Conde, logo a seguir ao desaire da Liga Patriótica do Norte, afirmando "estava morto como cidadão - e estava realizado essencialmente como pocta e filósofo" (Cf.ob. cit.,p. 45). Não podemos concordar com tais pressupostos. Nem o cidadão nem o filósofo estavam mortos. $O$ cidadão tinha preocupações familiares com as filhas adoptivas, ao ponto de renunciar a viver em Vila do Conde e transferir-se para S. Miguel. O filósofo permanecia bem vivo. As Tendências Gerais da Filosofia estavam inacabadas. Depois o testamento foi um acto cautelar, natural e vulgar num cclibatário, e já fora concebido por Antero antes do desastre da Liga, conforme cle afirma a José da Cunha Sampaio: "deves comunicar ao Alberto (...) que fiz finalmente o testamento, aquele sobre que te consultei há um ano. (...) O Alberto que tome nota disto, como testamenteiro e tutor das pequenas, pode ter de intervir se por qualquer caso esta máquina se escangalhar mais cedodo que se prevê" (Cf. Cartas II, ob. cit., c. 649, a José da Cunha Sampaio, Setembro de 1890, p. 1010, sublinhado nosso). Como se vê o pocta-filósofo nem prevê para breve a sua morte. 0 testamento é apenas uma medida cautelar.

$\left({ }^{76}\right)$ António Sérgio, "Os Dois Antcros", in Ensaios $N$, Lisboa, Sá da Costa, 1981, pp. 129-160.

$\left.{ }^{7}\right)$ Marco Paulino e J. Dias Cordciro estabclecem um quadro de sintomas que uma 
estômago, nas dificuldades digestivas, na insóna continuada, no cansaço a que repetidamente alude, nos sentimentos de infortúnio pessoal e familiar, na irritabilidade às vezes sem motivo, na dificuldade de concentração, é, depois, contrabalançada por uma actividade intensíssima, desdobrando-se em múltiplas tarefas, multiplicando-se por inúmeras iniciativas, projectando no microcosmos da sua existência colectiva a energia positiva que, arrebatando-o, arrebatava companheiros e amigos $\left({ }^{8}\right)$. O "príncipe da mocidade" que, pelo impulso da inteligência lúcida e aberta a todo o conhecimento novo $\left({ }^{9}\right)$, é o timoneiro, ainda que muitas vezes involuntário, da sua Geração. No entanto, este Antero "luminoso" tem em si, mais do que um Antero "nocturno". Há nele um homem prismático que, depois de cada arremetida, após cada derrota, entre dois renascimentos, mergulha nos mais profundos estados depressivos. Antero é um tímido. As relações amorosas frustradas, a inibição da sexualidade, a idealização dos objectos das suas paixões, tudo concorre para a procura do isolamento, para dirimir as maiores angústias na solidão das grandes

avaliação diagnóstica de Ansiedade Generalizada deve ter em conta. Dividindo os sintomas em quatro categorias basta que se verifiquem três das quatro categorias para se definir aquele quadro clínico.

Esta formulação, produzida em abstracto, se for cotejada com aquilo que se conhece de Antero de Quental permite esclarecimentos interessantes que vale a pena mobilizar para o presente estudo, particularmente porque fortalecem a tese de que ele padecia de Distúrbio Afectivo Ciclotínico, conforme admite Jorge Costa Santos.

Vejamos, pois, as categorias propostas por M. Paulino e J. Dias Cordeiro: 1 - Tensão Motora: humores, dores musculares, fatigabilidade, incapacidade de relaxar, sobrancelhas franzidas, face fatigada, inquietação, sobressalto fácil; 2-Hiperactividade Vegetativa: dispepsia, arrepios, diarreia, dores abdominais, "bola" esofágica; 3 - Expectativa Apreensiva: ansiedade, aflição, ruminação e antecipação do infortúnio do próprio; 4 - Vigilância: hiperatenção resultando em distracção, dificuldade de concentração, insónia, sensação de estar à "beira de", irritabilidade, impaciência (Cf. Idem, "A Ansiedade em Medicina, Cirurgia e Psiquiatria" in Manual de Psiquiatria Clínica, dir. J. C. Dias Cordeiro, Lisboa, Fund. Calouste Gulbenkian, s/d, p. 197).

Se concatenarmos tais tipificações com os períodos depressivo e hipomaníaco de Antero, verificamos que, praticamente toda a sintomatologia descrita é motivo de preocupação ao longo do espistolário anteriano. Recorde-se como, já atrás referimos, na fase final da vida e da doença, a maior parte destas queixas se amplifica a ponto de o absorverem completamente.

$\left.{ }^{78}\right)$ Sobretudo na organização das Conferências do Casino e na luta contra a proibição de que foram objecto, é possível identificar, em toda a plenitude, oentusiasmo contagiante de Antero.

$\left({ }^{79}\right)$ V. Eça de Queirós, "Um Génio que era um Santo", Anthero de Quental - In Memoriam, pp. 481-522. 
caminhadas, ou no círculo estreitíssimo de amigos onde consegue ser expansivo.

Poroutro lado, o misticismoc a elaboração filosófica, matcrializados nos trabalhos publicados, em verso e prosa, são a expressão extcrna do seu sentir mais profundo. A leitura sincrética da cpistolografia e dos trabalhos públicos, largamentc documentados nas Prosas ${ }^{\left({ }^{80}\right.}$ ), põe em evidência o resvalar de Antero para o caminho trágico onde terminou os scus dias.

Vcjamos, sucintamente, alguns dos momentos mais significativos desta trajectória existencial.

Em 1861 publica o primeiro livro - Sonetos de Anthero, e no ano seguinte, encontramo-lo liderando a Sociedade do Raio, $\mathrm{cm}$ confrontação clara com o reitor da Universidade de Coimbra. Redige o Manifesto dos Estudantes de Coimbra a Opinião Ilustrada do País. Activamente cmpenhado no combate, em Outubro de 1862, contava 20 anos, saudando o Príncipe Humberto, humilha o reitor, insinuando publicamente que se tratava de um "fantasma do passado" ( $\left.{ }^{81}\right)$. O reitor demite-se. Antero c o seu grupo ganhara o combate, mas logo af, o jovem guerreiro cai $\mathrm{cm}$ prostração, revelando a Francisco Faria e Maia, o estado de angústia e depressão $\mathrm{cm}$ que se encontra ${ }^{82}$ ): "Quisera escrever-te mais, mas não posso. Estou doentíssimo, daquela doença que faz um ano nos atacou; que dilata o cércbro; dissolve as ideias; relaxa a fibra da vontadc; e nos faz ver o mundo através dum fundo de uma garrafa, baço e de desusada catadura. É cssa a minha doença".

Em Agosto de 1865 sai a primcira edição das Odes Modernas prenhes de entusiasmo e espcrança revolucionária. Desde cntão, e até fins de Outubro do mesmo̊ ano, conhecem-se oito cartas de Antero. As primciras quatro tratam do livro publicado e retratam a incontida ânsia de saber reacções e críticas. Nos finais de Outubro, passada a euforia

$\left.{ }^{(80}\right)$ Antero de Quental, Prosas, 3 vols., Imprensa da Universidade de Coimbra, $1923,1926,1931$.

$\left.{ }^{(81}\right)$ O discurso então prof crido por Antero está publicado no Archivo dos Açores, vol. XII, Ponta Delgada, 1892, p. 186, c reproduz a minuta original que se cncontrava colada ao álbum de João Machado Faria c Maia. A data de 22 de Outubro de 1892 que aí se encontra é, naturalmente, uma gralha de composição, já que o discurso foi produzido em 22 de Outubro de 1862.

${ }^{(82}$ ) Cartas I, ob. cit., c. 10, a Francisco Machado Faria c Maia, 1863, p. 25. 
da publicação e confrontado com o fracasso editorial, escreve a António de Azevedo Castelo Branco ( ${ }^{83}$ ) e retorna ao tema da doença. O declive para a depressão estava aberto, não fosse a publicação do folheto Bom Senso e Bom Gosto que iria desencadear a Questão Coimbrã. Na carta onde anuncia para breve a saída a público desta prosa, é visível a euforia $\left({ }^{84}\right) \mathrm{e}$, temos por certo, que é a expectativa de um novo combate que o inibe de maior desalento, pois que, como observa em post-scriptum, das Odes apenas se tinham vendido 14 exemplares.

A partir de finais de 65, a Questão Coimbrã explode. Antero surge como o demiurgo deste apocalipse feito de desabridas polémicas. $\mathrm{O}$ folheto Literatura Hoje de Ramalho Ortigão espicaça o temperamento irritável do polemista e a 7 de Fevereiro de 1866, três meses depois do início da contenda intelectual, os dois batem-se em duelo. Antero fere Ramalho c a buliçosa comunidade académica coimbrã rejubila. Só que esta comunidade não sabe que, dois dias antes da disputa armada, o seu Apolo confidenciava este surpreendente estado de espírito $\left({ }^{85}\right)$ : "O que eu quero porém é terminar com isto que, sobretudo no meu estado de quase desespero, me aborrece mortalmente"; e, mais adiante, noutro passo da mesma carta: "estou efectivamente desassossegado e muito; mas como não estar? Cada vez sinto mais o falso da minha posição nesta terra lusitana. Não me entendo com os homens, coisas: apenas com os céus e os montes, mas isto não é suficiente".

Antero bate-se por uma Questão que já não o interessava e, já após o duclo, corolário físico violento de uma disputa intelectual violenta, exclama repugnado $\left({ }^{86}\right)$ : "Sinto entre mim e o meu país a distância abismosa deste sentimento, o desprezo... Resolvi calar-me para sempre entre cstes homens. O silêncio é a única resposta possível".

Magoado, transtornado pela exaltação da polémica afasta-se para longc. Em fins de Março está em Ponta Delgada c é neste estado de espírito que deixa o Continente $\left({ }^{87}\right)$ : "Relê as minhas últimas cartas:

(33) Ibidem, c. 27, a António A. de Castelo Branco, fins de Outubro de 1865, pp. 54.

(84) Ibidem, c. 32, a António A. de Castelo Branco, 4/5 de Fevereiro de 1866, p. 65.

${ }^{85}$ ) Ibidem, c. 28, a António A. de Castclo Branco, fins de Outubro de 1865, pp. 55-56.

$\left.{ }^{86}\right)$ Ibidem, c. 33, a António A. de Castclo Branco, depois de 7 de Fevereiro de 1866, p. 67.

${ }^{(87)}$ Ibidem, c. 36, a António A. de Castelo Branco, 14 de Março de 1866, p. 71. 
[escreve a A. Castelo Branco] cada uma delas deve parecer já um degrau de escada que leva à loucura. Tenho medo dela. Prefiro fechar os olhos c mergulhar de salto na monotonia da vida da família, a arrostar com o doloroso imprevisto de tentativas e ensaios de vida social (ou extra-social) para que já não sinto força nem mesmo invenção. (...) Isto é um desgosto imenso de todo o passado. Quebro violentamente com cle; ponho a sericdade $\mathrm{e}$ as considerações da famflia cntre mim c a possibilidade de voltar à vida antiga (...) Além de tudo fujo a um amor sem futuro".

Como se vê Antero parte, fugindo ao amor e ao passado. Não houvesse mais indicações e o leitor desatento poderia admitir que 0 regresso ao lar cra uma decisão definitiva. Porém, logo em fins de Março, já mudou de opinião ${ }^{88}$ ): "Resolvi não me demorar aqui mais do que até ao fim do verão - 6 ou 8 meses - Para onde irci? ignoro: talvez, daqui atć lá, indaguc dum emprego para a Índia, para Goa ou Macau".

Entrctanto, não foram precisos 6 ou 8 meses para decidir para onde haveria de partir. No verão de 1866 já estava em Lisboa, trabalhando na Imprensa Nacional. Nos finais deste verão, decidira "sair do país o mais cedo que possa" e cm princípios de Dezembro escreve de Paris. Desalentado e decepcionado regressa a Portugal c no outono de 1867. está outra vez, $\mathrm{cm}$ Ponta Delgada e, por aqui se fixa durante um ano, para regressar a Lisboa. Afinal o que procura este Antero vagabundo, crrantc $\mathrm{c}$ inscguro, que qucr e não quer, que fica mas parte, como um náufrago à deriva pclos caminhos da vida? Vejamos como ele procede ao scu próprio diagnóstico $\left({ }^{89}\right)$ : "Tenho-me fiado demais no meu coração: cle é fraco; combatentes da realidade assustam-no; a frieza dos homens perturba c entristece o meu espírito um tanto e naturalmente mórbido e delicado de místico. Este misticismo, esta feição abstracta e contemplativa, que me dá uma força suficiente em face das ideias e dos sistemas, que não se aterra com as maiores coisas sendo apresentadas na sua forma impessoal $\mathrm{c}$ abstracta, $\mathfrak{c}$ isto exactamente o que na vida, na acção, na luta da realidade me enche de fraqueza e perturba a ponto de perder a consciência de certas noções claríssimas de bem e de mal,

\footnotetext{
$\left.{ }^{(88}\right)$ Ibidem, c. 37, a António A. Castelo Branco, fins de Março de 1866, p. 73.

${ }^{89}$ ) Ibidem, c. 38, a António A. Castelo Branco, Abril de 1866, p. 75.
} 
justo e injusto, moral e imoral. Perco o sentimento do Real, falta-me o pé nesta corrente da vida social, pareço outro...".

Dias depois, completa este raciocínio numa carta a Germano Meireles $\left({ }^{90}\right)$ : "É que ninguém sabe como eu tenho magoado e sensf́vel o coração! só a frieza, a aparência glacial dessa gente, a simples vista dos homens, me aflige e faz sofrer. Aqui mesmo [escreve de Ponta Delgada] não há talvez 20 pessoas que me tenham visto. Mas este excesso de sensibilidade doentia me adverte que preciso scr homem, endurecer um pouco, lutar, porventura".

Datam desta altura, de 1865 , os primeiros trabalhos filosoficos, "A Bíblia da Humanidade de Michelet", "O sentimento da imortalidade", "Espontaneidade", "O futuro da música".

Não consideramos ser exagerado admitir que a instabilidade de Antero, a procura de rumos que tacteia de experiência em experiência, estão intimamente ligados à exploração dos caminhos por onde deseja articular o discurso filosófico, ainda não amadurecido, na procura da significação da essência metafísica da existência. Vivendo um tempo de mudança, de bruscas mudanças, poderíamos dizer, o místico e sensível Antero toma uma consciência pessimista da vida, onde a acção ganha uma definição subjectiva e espiritualizante. Verificar-se-á pela trajectoria existencial expresssa nas Cartas. Apcsar das múltiplas arremetidas na vida activa, com principal realce para as Conferências do Casino, para a actividade militante na formação da Associação de Trabalhadores e na elaboração de um programa de prática socialista, vive angustiadamente a necessidade de estabelecer um sistema filosófico coerente que exponha a sua concepção de Evolução.

As abortadas Conferências do Casino de 1871, organizadas sob o impacto dos acontecimentos da Comuna de Paris, as várias impossibilidades endémicas de organização do movimento operário que se traduzem na anemia da Associação de Trabalhadores, a grande desilusão que foi a experiência republicana espanhola de 1873, o empenho na União Democrática, a crftica literária, são acontecimentos vividos com paixão e entusiasmo, para depois, em cada derrota se manifestar a hipocondria dos scus cstados de espírito. "Tenho estado docnte, e com febre, e impossibilitado deste modo de ler coisa que me

$\left.{ }^{(90}\right)$ Ibidem, c. 39, a Germano Meireles, 30 de Abril de 1866, p. 77. 
pedisse muita atenção" $\left.{ }^{91}\right)$, comunica a Teófilo Braga, semanas depois de proibidas as Conferências. Depois de activa participação da formação da Aliança Democrática Socialista, do trabalho de militância socialista do qual sairá o opúsculo "O que é a Internacional", do empenho no aprofundamento com organizaçðes operárias e socialistas espanholas, volta à doença: "tenho passado mal de corpo e de espírito o suficiente para não prestar para nada há 2 meses. De corpo com os meus desarranjos nervosos, insónias, etc. de espírito, atacado porum daqueles períodos de abatimento e indiferença budista que são próprios do meu temperamento (...) A doença de um modo ou de outro, é o meu estado normal" $\left({ }^{92}\right)$.

Este cruzamento de actividade-doença vai tomar aspectos mais graves. Em 13 de Abril de 1873, despedindo-se de Oliveira Martins, na partida para S. Miguel, devido à morte̊ do pai, numa breve crítica aos artigos que o amigo escrevera no Jornal do Comércio, afirma $\left({ }^{93}\right)$ : "Nada de definitivo se pode aclarar sobre o assunto enquanto não houver feito uma teoria positiva (metafísica e cientifica) da Evolução, coisa que não se fez ainda, nem fará tão cedo, e sem a qual a filosofia da História continuará por muito témpo ainda num período mais subjectivo do que positivo".

Ora é sobre a teoria da Evolução que assenta o objectivo central do trabalho a que, à altura, se entregava sob o título Programa de Trabalhos Para a Geração Nova, e cujo início podemos marcar no rescaldo das proibidas Conferências do Casino $\left({ }^{94}\right)$, a partir da segunda metade de $1871\left({ }^{95}\right)$.

Vamos ver como este ambicionado projecto vai ter efeitos

(91) Ibidem, c. 77, a Teófilo Braga, fins de Junho de 1871, p. 142.

${ }^{(22}$ Ibidem, c. 90, a Oliveira Martins, 18 de Janciro de 1872, p. 159.

$\left({ }^{93}\right)$ Ibidem, c. 105, a Oliveira Martins, pp. 188-190.

(94) As Conferências tiveram início a 22 de Maio e foram suspensas no dia 26 de Junho, quando o judeu Salomão Sáragga ia dissertar sobre os "Historiadores Críticos de Jesus".

(95) E numa carta a Teófilo Braga, de Julho de 1871 (Cf. Cartas I, ob. cit., c. 75, pp. 139-140) que fornece a primeira indicação de que está a trabalhar no Programa de Trabalhos, "que ć uma exposição das ideias revolucionárias: filosóficas, económicas e morais. Mas quando o poderei fazer? A acção faz perder um tempo precioso, e indispõe o espírito para o trabalho meditativo. Verei se tenho paz e concentração este verão para estudar e escrever". 
devastadores no Distúrbio Afectivo de Antero, mergulhando-o num dos períodos mais dramáticos da sua vida, deixando-lhe sequelas que os outros combates perdidos não tinham produzido.

\subsection{Entre o "Programa da Morte" e a "Morte de um Programa"}

Percorrendo o epistolário de Antero, podemos afirmar que desde o verão de 1871 até finais de 1873 , se dedicou com afinco à elaboração do sistema filosófico a que dera o nome de Programa de Trabalhos Para a Geração Nova. Comenta-o em várias cartas, particularmente na correspondência com Oliveira Martins, explicando os caminhos que está a explorar, a organização que lhe imprimiu, os objectivos que pretende conseguir. Embora com algumas intermitências justificadas por razð̃es de saúde, trabalha com entusiasmo. E tanto é assim que, tendo partido para Ponta Delgada, em Abril de 1873, para tratar de assuntos decorrentes do falecimento do pai, decide aí permanecer para com mais tranquilidade concluir o estudo a que se propôs $\left({ }^{96}\right)$.

Em Julho desse ano, informa Oliveira Martins $\left({ }^{97}\right)$ que dar a seis ou sete meses terá o Programa concluído e espera, então, regressar a Lisboa. Até finais de Novembro é notório o entusiasmo com que trabalha. Porém, é nesta altura que surgem os primeiros indícios de angústia $\left({ }^{98}\right)$ : "a contensão terrível do meu pobre espírito, amarrado, acorrentado, como um potro, como uma cruz, à dedução das ideias que o trabalho do meu livro vai erguendo diante de mim (vendo abismos de um lado, vendo muralhas de outro) numa palavra, estado de parto, $\mathrm{e}$ está tudo dito, essa contensão chega em momentos a produzir em mim

${ }^{(96)} \mathrm{O}$ estudo a que se propôs centra-se, sobretudo, na construção de sistema filosófico explicativo da Evolução. No que se refere à abordagem filosófica do discurso anteriano, dos numerosos trabalhos publicados, destacamos aqueles, que no nosso entender, melhor tratam o problema e que tomámos como nosso referencial: Fernando Catroga, "A Ideia de Evolução em Antero de Quental", Biblos, n. ${ }^{\circ} 56$, Coimbra, 1980 , pp. 357-388; e, ainda, "A Metafísica Indutiva de Antero de Quental", Biblos, n. ${ }^{9} 61$, Coimbra, 1985, pp. 472-507; Joaquim de Carvalho, "A evolução espiritual de Antero" in Obra Completa de Joaquim de Carvalho, Lisboa, Fund. Calouste Gulbenkian, vol. IV, pp. 545-696; e "Morte e imanência no pensamento de Antero de Quental", ibidem, pp. 533-544; José Marinho, Verdade, condiçāo e destino no pensamento português contemporâneo, Porto, Ed. Lello \& Irmão Editores, 1976, pp. 39-56.

${ }^{(97)}$ Cartas I, ob. cit., c. 92, a Oliveira Martins, 7 de Julho de 1872, pp. 164-165.

${ }^{(98)}$ Ibidem, c. 121, a Oliveira Martins, 26 de Novembro de 1873, pp. 225-226. 
(que sou fraco de cérebro) uma coisa semelhante à imbecilidade. Com os olhos num ponto único, arregalados num esforço violento para penetrar a forma de uma ideia que não quer sair do vago, não vejo mais nada, e o que tudo mais entendo é como que pelo tacto, como que às apalpadelas".

Um mês depois, em finais de Dezembro $\left({ }^{99}\right)$ numa outra carta a Olivcira Martins, aborda pela última vez o trabalho no Programa. Depois de criticar argutamente o monismo de Haeckel, aclara 0 travcjamento do conccito de Evolução que desenvolve e termina com algumas afirmações onde se percebe um certo desespero: "a metafísica é hoje repclida universalmente da Filosofia da Natureza. Não importa. Irei de encontro à onda dos positivistas, materialistas, empíricos e tutti quanti, convencido de que não passará muito tempo sem que constituída a metafísica positiva, a Filosofia da Natureza entre no caminho verdadeiro".

A carta seguinte que se lhe conhece é de Março de 1874 a Jaime Batalha Reis $\left({ }^{100}\right)$ : "Infelizmente (ou felizmente, $\mathrm{cm}$ boa filosofia são advérbios cquivalentes) chegou mais rápido do que calculci o período de desorganização. A minha doença - a mesma que sabc, mas agora "correcta c aumentada" - já me não dão senão um outro dia excepcional de vida activa, livre, humana (...) doença cuja acção é sobretudo no cércbro, entibiando cruelmente o entendimento e a vontade (...) Assim vivo há mescs, mcu caro amigo, e assim cuido acabar".

Repare-se que fala em meses de doença, o que talvez explique 0 intervalo de Dezembro a Março, sem qualquer correspondência. Mas antes de continuarmos, vejamos como Ana Guilhermina, mãe de Antero, allita, descreve o cstado de saúde do filho, num extracto de uma carta publicada por José Bruno Carrciro $\left({ }^{101}\right)$ : "porque vejo que cle vai cada vez pior, muito magro, muito abatido, muito desanimado (...)

\footnotetext{
$\left({ }^{99}\right)$ Ibide'm, c. 122, a Oliveira Martins, 26 de Dezembro de 1873, pp. 230-232.

$\left({ }^{100}\right)$ Ibidem, c. 123, a Jaimc Batalha Rcis, Março de 1874, pp. 233-235. É na sequência desta carta, que a 5 de Maio de 1874 (c. 126, p. 239) sossega o amigo, dizendo-lhe: "V. parece julgar que cu esteja disposto a suicidar-me, duma mancira por assim dizer negativa, isto é, deixar-me morrer, placidamente sem luta, sem fazer da minhaparte-c prova-me que istoć ainda suicídio e por conseguintc ímpio. Perfeitamente mas cu não cstou disposto a tal (...) estou disposto a seguir tudo quanto for neccssário para não parecer que me quero suicidar".

$\left({ }^{101}\right)$ José Bruno Carreiro, ob. cit., 2. ${ }^{9}$ vol., pp. 18-19.
} 
e num estado de susceptibilidade nervosa que qualquer coisa o aflige, e mesmo irrita".

É neste tempo que Oliveira Martins corre a S. Miguel alarmado com o estado em que se encontra o amigo e a que já fizemos referência noutro momento do presente estudo. Vai começar, a partir de agora, a longa e penosa peregrinação através da doença durante cerca de sete anos. Doenças na espinha, doenças no estômago, histerismo, neurastenia, são alguns diagnósticos que olevam a tratamentos dolorosos e prolongados, incluindo a viagem a Paris para ser visto por Charcot. S6 em princípios de Março de $1875\left({ }^{102}\right)$ se toma a referir ao Programa. Deste período de dois anos conhecem-se vinte cartas e nenhuma tem qualquer alusão à sua obra filosofica. Estuda muito, reflecte sobre a filosofia da História, especula sobre a teoria da Evolução, e, sobretudo, prossegue a obra poética dos Sonetos. O soneto "A Um Crucifixo II" é escrito em Agosto de $1874\left({ }^{103}\right)$. O soneto "O Inconsciente" $\left({ }^{104}\right)$ é de finais do mesmo ano. Porém, as melhoras são poucas e estamos em crer que a melhor terapêutica que aplicou foi, em 1880 quando decidiu adoptar as órfãs de Germano Meireles, e passou a ter famńlia, pois que, a partir de então diminui sensivelmente a quantidade de queixas sobre a doença.

Porém, antes de continuarmos, há uma questão fundamental que não podemos adiar, face à dramática experiência vivida por Antero desde princípios de 1874: foi a doença que lhe impediu a conclusão do Programa $\left({ }^{105}\right)$ ou foi a impossibilidade de o concluir que conduziu ao agravamento da doença?

(102) Uma última referência que parece ser ao Programa aparece numa carta a Oliveira Martins, datada de princípios de Março de 1875 (Cf. Cartas I, ob. cit., c. 146, pp. 270-271), e já lhe chama "Ensaio".

$\left({ }^{103}\right)$ Publicado na 2." edição das Odes Modernas de 1875.

(104) Consta de uma carta a João Lobo de Moura, de fins de 1874 (Cf. Cartas I, ob. cit., c. 142, pp. 264-265).

$\left({ }^{105}\right)$ Acreditamos que Antero de Quental suspendeu definitivamente a claboração do Programa dos Trabalhos para a Geraçāo Nova nos fins de Dezembro de 1873 . O facto de o tornar a referir em 1875, ainda que fugazmente e de forma inconclusiva, é, na realidade, do Programa ou de qualquer outro trabalho (chama-lhe Ensaio) que virtualmente tenha destruído. José Bruno Carreiro refere que o jomal $A$ República chegou a anunciar a sua publicação (Cf. ob. cit., $2 .^{\circ}$ vol., p. 489). Não damos a esta notícia outro valor que não seja a certeza de que àqucla data - 1875 -, ainda não fora destruído.

Merecem-nos, ainda, algumas reservas o depoimento do poeta Manuel Duarte de 
Tendo em conta os aspectos psicologicos, a instabilidade psicossomática, as várias componentes que tipificam os Distúrbios Afectivos Ciclotímicos, os quais temos vindo a mostrar ao longo deste trabalho, somos levados a concluir que foi a incapacidade teorética de Antero para concluir o seu sistema que potenciou os mais evidentes sintomas da grave doença do foro psíquico que o. atingira. Histeria ou neurastenia, como então lhe foi definida, a incapacidade médica para solucionar em bom termo a patogenia que o vitimara, deixava o campo aberto à recidiva. Quando esta aconteceu, o disparo final foi o corolário deste prolongado drama existencial.

\subsection{O "Suicídio" do Poeta}

O Poeta que agitou a mocidade que, temerário, investiu contra a couraça do ultramontanismo romântico, o Poeta que "escreve o que sente, e sente o que escreve", esse raio de luz não extinta no qual radicam movimentos poético-filosóficos posteriores, mata-se de um só golpe. Terá sido, no nosso entender, a mais definitiva das decisões que Antero tomou contra si.

A última compilação de sonetos $\left({ }^{106}\right)$ que publicou, e à qual quis associar o seu prolongamento activo Oliveira Martins, ganhou logo a dimensão de um epitáfio grandioso e universalista. Traduzido em alemão por Storck que, até então, só considerara digna de publicação na

\footnotetext{
Almeida (Cf. Anthero de Quental - In Memoriam, pp. 361-362) que informa que Antero leu o Programa "que tão profunda impressão provocaram no grupo selecto que lhos ouvira ler [a obra constava de dois volumes] e onde, é bem que se diga, não escasseavam competências para julgar, nem tão pouco inteireza e hombridade, para, lealmente e sem biocos, exprimir ao autor o seu assentimento ou a sua desaprovação". Como se vê pela construção formal da narrativa não fica claro que Manuel Duarte Almeida estivesse nesse "grupo selecto" de ouvintes. Depois urge perguntar: quem era o "grupo selecto?" O conhecimento que temos de Antero leva-nos a admitir que não fossem outros, senão os seus amigos íntimos, Oliveira Martins, Batalha Reis, Castelo Branco, Junqueiro, Jaime Magalhães Lima, Eça, Joaquim Araújo, os irmãos Sampaio, e mesmo nos Açores, os irmãos Faria e Maia. Porém, nem Duarte de Almeida diz qual é o grupo, nem nenhum destes dá conta de terem lido ou ouvido ler o Programa. Sousa Martins que também alude a esta hipotética leitura, também não assistiu. Estamos em crer que a única leitura do trabalho terá sido feita por Oliveira Martins, em Ponta Delgada, em Abril de 1874, quando visitou o amigo, alarmado com o seu estado de saúde.

$\left({ }^{106}\right)$ Sonetos Completos, publicados por J. P. de Oliveira Martins, Porto, Liv. Portuense de Lopes e C.: Editores, 1886.
} 
sua língua mater a poética de Camőes, de entre os autores portugueses; traduzido em inglês (Alice Moderno reproduz algumas dessas traduções no In Memoriam), em italiano, em castelhano, esta morte anunciada do Poeta é o prenúncio apoteótico de uma imortalidade em que não acreditava e que deixa explícito na "certidão de óbito" que assina $\left({ }^{107}\right)$ : "A propósito de versos, dir-te-ei que já não os faço. Secou-se-me a fonte viva: e, como depois de ter sido poeta não quero continuar sendo versificador, parei. Como despedida, vou imprimir a colecção completa dos meus Sonetos (...) espécie de autobiografia psicológica (...) se de mim ficar alguma coisa nas letras portuguesas, creio que será esse livrinho. E e assim que a gente entra na arena bramindo armas que prega mágicas, para conquistar o mundo (ou um mundo), e afinal acaba por conseguir modestamente um lugarinho entre os poetae minores.

Vários anterianistas têm visto nesta decisão o fim da inspiração poética e, por via disso, os Sonetos Completos encerram um ciclo natural a que Antero decidira porr um remate final. Mas, ter-se-ia, de facto, secado "a fonte viva" de onde lhe brotava cada soneto, sentido e vivido? Pensamos que não. O Poeta trai-se, no que respeita às razões deste suicídio, quando em Dezembro de 1885, confessa em tom expansivo e sincero a Jaime Batalha Reis $\left({ }^{108}\right)$ : "Em primeiro lugar, vou bastante melhor (...) empreendi, só com a força de vontade e da razão, não só curar a nevrose, mas transformar um temperamento. É diff́cil mas não impossível, e creio que alguma coisa levo já alcançada. Este processo implicava uma morte violenta: a do poeta que em mim havia".

Nao foi, portanto, por se lhe ter secado "a fonte viva" que "matou" o Poeta. Como deixa bem explícito essa morte violenta resulta do esforço para "curar a nevrose" e "transformar o temperamento". Mas esta terapia leva-nos a outra questão: de que forma a pocsia poderia ser um perturbador da sua psicopatogenia e intervir negativamente no temperamento?

Olhemos Antero à luz dos projectos que acalentou e do estado de espírito desde os anos de Coimbra. A poesia, a intervenção política, 0 p. 741

(107) Cartas II, ob. cit., c. 461, a António A. de Castelo Branco, 6 de Junho de 1885 ,

( $\left.{ }^{108}\right)$ Ibidem, c. 476, a Jaime Batalha Reis, 24 de Dezembro de 1885, p. 761. Sublinhado nosso. 
debate público são sustentados na idealização de um sistema de comportamentos éticos e morais que procuram, em última instância, a verdadeira essência da existência no quadro da evolução ôntica. Este processo gnosiológico é, essencialmente de cariz filosófico, e em Antero a filosofia confunde-se com o misticismo intrínseco a propedêutica vivencial que condiciona o seu discurso metafísico. Estamos em crer, que reside neste estado de espírito não superado um dos mais profundos dramas do poeta-filosofo. Se o místico se assume na clara identificação do sujeito e do objecto, expressando esta sintonia subjectiva através da poesia, como forma literária mais consentânea com tal estado de espírito, o discurso filosófico exige distanciação critica entre sujeito e objecto, exige a hermenêutica do conhecimento e forte vigilância crítica do $\mathrm{Eu}$ em relação à articulação ideologica que realiza.

Antero vive este dramático conflito. $\mathrm{O}$ misticismo franciscano e budista, pampsiquista e apostado na tangibilidade do Bem Universal, de inspiração hegeliana, tem na poesia a forma privilegiada de se exprimir, porque lhe activa a emotividade espiritualista, característica fundamental do seu complexo psicológico. Ou seja, o místico pela natureza transcendental da atitude existencial, assume-se na indissociação do sujeito e do objecto e a criação poética absorvendo esta postura interiorista, transforma-se no discurso confessional desta unidade simbiótica.

Não sabemos qual a razão que levou Antero à destruição do inacabado Programade Trabalhos para a GeraçãoNova, mas sabemos que também, já depois de ter "morto" o poeta, deixou por concluir o maior trabalho filosófico que se lhe conhece - As Tendências Gerais da Filosofia na Segunda Metade do Século XIX.

Joel Serrão ${ }^{(109)}$ propõe como exercício de imaginação, tentar compreender o suicídio como a destruição definitiva do Programa iniciada quinze anos antes. A proposta é aliciante mas não nos parece segura. O seu programa filosófico não o leva à pistola e ảo disparo, condu-lo à evidência da doença psíquica de que sofre e ao suicídio do poeta. Um suicídio pensado, reflectido entre a tormenta da doença e 0 misticismo que o impele para os sonetos. $\mathrm{O}$ "tratamento" da nevrose e

(109) Joel Serrão, "Antero de Quental" in Dic. História de Portugal, Porto, Liv. Figueirinhas, vol. V, pp. 213-218. 
modificação do temperamento foi aparentemente ineficaz. A doença persiste, otédio, problemas de bexiga, estados melancolicos prolongados são algumas das indicações de um rol interminável de queixas que debita nas Cartas.

A angústia de Antero revela, ainda, um homem afectivamente carente. "Depois da morte de minha mãe e do casamento da minha irmã, acho-me só de famf́lia, e pertenço naturalmente aos amigos" $\left({ }^{110}\right)$. E numa outra carta: "A dispersão e ruína da nossa famnlia causa-me grande melancolia, que tu bem compreendes, pois sei que a sentes igualmente" $\left.{ }^{111}\right)$. Nesta confissão a Ana de Quental, assenta um dos tópicos fundamentais, a nosso ver, das perturbaçð̃es emocionais de Antero de Quental. A instabilidade emocional e afectiva é um traço marcante de toda a vida. De alguma forma atenuada com a adopção das orfass de Germano Meireles, o retiro em Vila do Conde vai mostrar como se esbatem alguns dos conflitos interiores. É o período da vida onde lhe vislumbramos maior quietude espiritual, aparecendo-nos um Antero renovado, e rejuvenescido, nos longos passeios entre a solidão do campo e a contemplação do mar de Vila do Conde. O retumbante êxito dos Sonetos Completos têm ocondão de mostrarem a componente narcísica da personalidade $\left({ }^{112}\right)$ e as queixas das doenças que lhe atravessam o epistolário praticamente desaparecem.

É o tempo de gestação do projecto filosófico e na placidez da solidão retorna ao sonho antigo, pelo qual suicidara o Poeta que havia dentro de si. "Por mim, a solidão não me afecta a inteligência, nem entibia o ideal: pelo contrário, é na solidão que mais me sinto viver intelectual e sentimentalmente - mas é uma vida 'ensimesmada', toda interior e subjectiva e por af exclusiva e viciosa, levando ao esquecimento da razão positiva e do próprio bom senso, afogado num nevoeiro de abstracções e sonhos, onde há o perigo de naufragar, juntamente com a vontade e amor das coisas naturais, a propria digni-

( $\left.{ }^{110}\right)$ Cartas I, ob. cit., c. 221, a Alberto Sampaio, 27 de Outubro de 1877, p. 395.

(111) Ibidem, c. 348, a Ana de Quental, 3 de Setembro de 1881, p. 573.

(112) As cartas dos anos de 1887 a 1889, na generalidade são alegres, com alguns laivos de vaidade incontida. As queixas de doenças praticamente desaparecem. $\mathrm{O}$ rápido êxito dos Sonetos Completos é um dos lenitivos mais eficazes para as doenças de Antero. A segunda edição que virá a público em 1890, já apresenta em apêndice as traduções que se fizeram da obra. 
dade do 'homem'..." ( $\left.{ }^{113}\right)$. Estas palavras escritas em 1874, cumpriam-se agora, no mais longo perfodo de sedentarização que viveu em Vila do Conde. Um Antero "ensimesmado", pocticamente morto, que no interior e subjectividade vai ruminando projectos e, mesmo em tempo de satisfação narcísica, tem a sinceridade para fazer a autocrítica intrínseca à sua exigência de rigor: "logo supus quando te mandei os meus Sonetos, que te haviam de causar uma impressão de tristeza. Mas que queres? Combinaram-se a doença, os desgostos e a evolução do meu pensamento, para, durante um período de anos, me porem num estado de espírito singular; singular pois tinha de ser a obra que dali saiu (...) pensando muito, e escutando docilmente o scgredar da consciência, pude emergir do pessimismo que me entencbrecia a existência e recuei no caminho da negação absoluta em que estava precipitado. É certo que a minha filosofia não mudou essencialmente (...) mas alargou-se, aprofundou-se, e sobretudo expurgou-se de elementos estranhos, que a perturbavam $\left({ }^{114}\right)$. Esta carta escrita no ano da publicação da "Filosofia da Natureza dos Naturalistas", contundente crítica ao sistema evolucionista monista de Haeckel e onde continua a procurar a síntese (já tentada no Programa de Trabalhos) do pensamento cientifico com o "universal idealismo" do pensamento metafísico. Este o trilho por onde procura o "Optimismo Transcendental" pampsiquista, o esteio da sua teoria da Evolução sobre a qual continua a reflectir.

Vila do Conde, exílio voluntário, onde Eça o vai encontrar sorridente e calmo, é o momento de maior amadurecimento do filósofo. Porém, nem aqui vai escapar às crises de melancolia, às insónias, a problemas de saúde que de novo, após o afrouxamento dos ecos do êxito dos Sonetos se começam a evidenciar, enquanto o misticismo o empurra para novas angústias, ao olhar o mundo que lhe vai à volta. "Tudo quanto se passa intra e cxtra muros produz-me um tal desgosto mudo e soturno, que ando há tempos como que embuchado (...) Há mais de oito dias que não abro um livro. Noutro tempo desesperava-me, e 0 desespero, agora o reconheço, era um alimento para o meu espírito: vivia disso. Mas agora, que já não posso descsperar, sinto um vácuo. (...) Que fazer a isto, e como viver no meio disto, ou pelo menos, com

(113) Cartas I, ob. cit., c. 128, a Oliveira Martins, 26 de Maio de 1874, pp. 242-243.

(114) Cartas II, ob. cit., c. 508, a Vicente Machado Faria e Maia, 1886, p. 810. 
isto diante dos olhos? O Budismo é uma bela coisa: mas a sua eficácia, como a de todas as religióes ou coisas análogas às religióes, só se evidencia na colectividade. Uma sociedade de budistas deve ser um paraíso. Mas um budista isolado é um pobre homem, a quem a sua transcendente sapiência só serve para bocejar. Ora vamos bocejando transcendentalmente" $\left({ }^{115}\right)$.

\subsection{Oúltimo combate de Antero}

Dura cerca de dez anos a permanência de Antero em Vila do Conde e, neste período, pelas condiçð̃es que temos vindo a descrever, há uma certa acalmia do estado psicopatológico e um claro esforço de reflexão filosofica. É aqui que decide "matar" o poeta, que escreve o Tesouro Poético da Infância particularmente dirigido às filhas adoptivas. Cremos que a tranquilidade que saboreia é indissociável do equilibrio afectivo e emocional decorrentes da vivência com as raparigas e do meio onde pode dar largas ao "peripatetismo" que tanto aprecia. "Vivo aqui, numa terrazinha morta, onde não conheço ninguém, com duas crianças que também não conhecem ninguém, além de mim. Esta singularidade de vida não é uma extravagância, mas em parte necessidade imposta pelas condições da doença, em parte como sistema por mim adoptado, para ver se chego a um equilíbrio, indispensável para qualquer espécie de trabalho. Se por este sistema me não curar, então nunca me curo. De resto, tenho um tal sossego interior, que posso dizer que sou feliz, no bom e único verdadeiro sentido da palavra. É um fruto da Filosofia, e quem me diria a mim, quando em Coimbra comecei a cultivá-la, que o que então era para mim só curiosidade da intcligência, viria agora a ser moral, fonte de energia c cscudo contra mil e um malcs!" $\left.{ }^{116}\right)$.

É, portanto, um retiro de gestação filosófica, amenizado pela segurança de poder, enfim, consumar o sonho acalentado desde os tempos de Coimbra: "A colecção dos meus Sonetos é o testamento do pobre poeta que acabou. Entro agora numa fase nova, e tenho jurado

\footnotetext{
(115) Ibidem, c. 566, a Oliveira Martins, 25 de Agosto de 1888, p. 897.

(116) Ibidem, c. 454, a Francisco Machado Faria e Maia, 28 de Março de 1885 , p. 729.
} 
consagrar-me daqui em diante, todo e exclusivamente ao trabalho de coordenação das minhas ideias filosoficase, se tanto puder, à exposição metódica e rigorosa das mesmas" $\left({ }^{117}\right)$.

Parece que Antero ganha o seu caminho. As cartas deste periodo, para além de uma atenção crescente a problemas familiares relativos às irmãs e ao irmão André, evidenciam um Antero activo, onde é possível perceber a trajectória da evolução filosófica em que mergulhou. Porém, este homem empenhado na reflexão metafísica, que "boceja transcendentalmente" perante os desvarios do mundo que o cerca, não perdeu o tumulto interior em que sempre viveu.

Abruptamente, por ocasião do Ultimato, volta a emergir como um meteoro na vida política $\left({ }^{118}\right)$, assumindo a presidência da Liga Patriótica do Norte. Os propósitos, atrás referidos, são esquecidos num ápice e em Antero ressurge o homem dos grandes combates. Pelo menos é neste estado de espírito que se prepara para a contenda ( $\left.{ }^{119}\right)$ : "O que se vai passar em Portugal é seríssimo. Faça cada um o seu sacrifício no altar da Pátria. Eu sacrifico a minha saúde, que naufragará de todo no meio disto, e muito provavelmente o meu nome, que antes de 6 meses estará manchado. Não importa. Quero sacrificar a vida e morrerei contente se tiver vivido 6 meses ao menos de verdadeira vida de homem que é a da acção por uma grande causa".

Não chegou a 6 meses essa vida de acção. O desempenho na Liga durante algum tempo, apenas vai servir para corroborar a ideia que tinha da necessidade de uma "Revolução espiritual e moral" com forte componente demopédica e o desastre dos projectos inicialmente idealizados, não o apoquentam sobremaneira; até, que sente

(117) Ibidem, c. 465, a Carolina Michaëlis de Vasconcelos, 7 de Agosto de 1885, pp. 747-749.

(118) É bem pouco o tempo que, na verdade, vai estar à frente da Liga. Aceitando o convite nos princípios de Fevereiro, dois meses depois já lhe prevê a morte "A Liga vai protestar. Boa ocasião para morrer sem vergonhas". Escreve a Luís de Magalhães, em Abril (Cf. Cartas II, c. 638, p. 995). Não se lhe nota um quadro de desespero ou de profunda angústia, como sucedeu noutros empreendimentos em que se envolveu. Nessa mesma carta, mostra o estado de espírito em relação à Liga: "Eu por mim estou farto disto e ansioso por um bom acabamento, que nos salve do inevitável fiasco. Mas dissolver-nos-ão? Há quem diga que não. Dcus os alumie!"

$\left({ }^{119}\right)$ Cartas II, ob. cit., c. 627, a Jaime de Magalhães Lima, 9 de Fevereiro de 1890. p. 980 . 
nessa falência política o reforço da sua teorética revolucionária, que lhe vai permitir afirmar a propósito da anemia do movimento a que presidiu $\left({ }^{120}\right)$ : "Morreu afinal de pura inanição (...) O que se passou este Inverno é a prova mais cabal do estado de prostração do espírito público entre nós".

Antero intervira no último combate político e cultural. A malograda experiência condu-lo ao abandono definitivo da vida pública e às palavras amargas com que se despede, de regresso ao "ensimesmamento": "Em Portugal não pode haver revolução que mereça este nome, porque a revolução pressupõe propósito, firmeza moral, o que aqui não há. Portugal é um pars eunuco, que só vive de uma vida inferior, para a vileza dos interesses materiais e para a intriga cobarde, que é o processo desses interesses. Não sei se a união ibérica se realizará: mas a fazer-se, far-se-á pela força das coisas e não pela intervenção livre e razoável das vontades, que as não há cá para tanto. Uma única é possível ou antes inevitável em Portugal: é a revolução da fome, mas essa ninguém precisa que ninguém a promova, nem pode ser matéria de programas políticos. Virá a scu tempo e fatalmente, como a conclusão necessária da desrazão e do egoísmo universais. Deixemos pois passar a onda providencial e tratemos simplesmente, como indivíduos, de conservar cada um em si um foco tão intenso quanto possível de força moral, de inteligência calma e sofredora, na preversão do espírito público, toda a csperança está posta nas virtudes morais (...) Versos já não os faço, nem tenho que dizer em verso. Em prosa teria muito que dizer, mas tão amargo e descaroável, tão longe de toda a esperança e consolação, que prefiro calar-me, ou antes, entendo que é mcu dever calar-me" $\left.{ }^{121}\right)$.

É um verdadeiro testamento político e, simultaneamente um grito agonizante. O revolucionário interventor extinguia-se e o revoltado, interiorizando a mágoa, desinteressado de lançar mais "uma ou duas ideias" inçandescentes que acendessem "a firmeza e a força moral" do país que, pelos combates travados vida fora, sempre procurara interpretar, decide calar-se.

Pocticamente suicidado, socialmente "ensimesmado", desistente da intervenção política que restava, então de Antero, "príncipe da

\footnotetext{
${ }^{\left({ }^{120}\right)}$ Ibidem, c. 643, (...), 22 de Julho de 1890, p. 1001.

(121) Ibidem, c. 652, a Alberto Osório de Castro, 25 de Novembro de 1890, pp. 1013 -1014 .
} 
mocidade"?

Um post-scriptum: numa carta a José da Cunha Sampaio $\left.{ }^{122}\right)$, de Fevereiro de 1890, escrita no auge do combate à frente da Liga Patriótica, comunicava-lhe: "Opróximonúmero da Revista de Portugal trará um artigo filosófico meu, o 1. duma série de 3, que irão a seguir. Conto depois ampliar aquilo e fazer dali um livrinho". Anunciava, desta maneira, aquilo que viria a scr a sua mais completa, embora inacabada, obra filosófica levada ao prelo-As Tendências Gerais da Filosofia na segunda metade do Século XIX, que por convite e incitamento de Eça de Queirós, escrevera durante o retiro de Vila do Conde. Nesses três artigos procede ao travejamento do sistema filosófico, assente na ideia da Evolução da essência do conhecimento $\left({ }^{123}\right)$.

Antero regressava a Vila do Conde e ao "bocejo transcendental". Tinha então, 48 anos e encontrava-se a pouco mais de uma dúzia de meses da morte. No entanto, a Liga não lhe provocara mazelas graves do estado de saúde; os sintomas depressivos e hipomaníacos típicos dos Distúrbios Afectivos $\left({ }^{124}\right)$ não se manifestavam, ou melhor, Antero não dá deles conta, nem mesmo se apercebe qualquer alteração significativa que permita concluir de um agravamento do estado de saúde.

A última referência epistolar aos projectos filosóficos é de Agosto de 1890, a Oliveira Martins ( $\left.{ }^{125}\right)$ : "Entretanto vou fazendo leituras e acumulando pensamento para, quando isso me for possível, voltar a completar o trabalho filosófico que publiquei na Revista e sobre a base do qual me parece que poderei fazer um livro que já se pareça alguma coisa com um livro. Mas não imagina quanto me aborrece cscrever! É também uma má disposição que preciso de corrigir". Não tornará a falar de semelhante projecto. As Tendências tal como o Programa de Trabalhos ficariam por concluir. E é aqui que nos surge uma questão inquietante: conhecido o percurso filosófico de Antero, sabendo-se da sua caminhada pela vida, quase sempre pelas bermas do abismo, enfraquecido por uma velhice precoce ditada pela doença, verificado o discurso vazado nos três artigos da Revista de Portugal, teria cle mais alguma coisa a acrescentar ao seu sistema? Estaria cm condi-

(12) Ibidem, c. 626, a José da Cunha Sampaio, 1 de Feverciro de 1890, pp. 978-979.

(123) Cf. bibliografia citada na nota 96.

(124) Cf. Apêndice - Entrevista Jorgc Costa Santos.

(125) Carlas II, ob. cit., c. 647, a Oliveira Martins, 21 de Agosto de 1890, p. 1007. 
çð̃es de prosseguir uma pesquisa que o pudesse levar ao aprofundamento do rigor central da análise existencial que, desde a juventude, arquitectara? ( $\left.{ }^{126}\right)$.

Desconhecemos a resposta a tal questão. No entanto, com base nos elementos de que dispomos, podemos afirmar que a partir da carta acima referida não tornará a aludir à conclusão do trabalho.

A partir de finais de 1890 começa a ganhar expressão nas preocupaçð̃es de Antero o crescente desejo de encontrar estabilidade afectiva, reconstituindo com as filhas adoptivas uma famflia no seio da qual encontre paz interior. Em Setembro de 1890 redige o testamento $\left({ }^{127}\right)$, medida cautelar de um celibatário de idade madura. Nos princípios do ano seguinte toma a decisão de regressar definitivamente a $\mathrm{S}$. Miguel, com as duas raparigas, acautelando a educação destas e prevendo maior intimidade com o que resta da famnlia, irmãos, primos e outros familiares.

Esta decisão não foi precipitada. Já de há muito tempo que ganhava força no espírito de Antero. Na verdade, em 1889, depois de ter regressado da ilha onde estivera cerca de oito meses para resolver problemas relacionados com a sua irmã Maria Ermelinda, escreve a Vicente Machado Faria e Maia ( $\left.{ }^{128}\right)$, dando-lhe conta deste projecto que, então, pensava para dar a dois anos, ou seja, para 1891: "Apeteço o sossego de que af se goza, c o horizonte que se vai entrevindo para Portugal é tão melancólico que prefiro muito vê-lo à distância. Depois o sentimento do ninho paterno é natural na velhice e eu caminho para velho. S6 espero por que as minhas pupilas estejam um pouco mais crescidas e educadas e creio que dois anos bastarão para isso!"

O tempo mostraria que esse apelo telúrico conduzi-lo-ia, não ao "ninho paterno", mas ao agravamento dramático da doença, e à

(126) Fernando Catroga afirma: "Não se pode estudar a evolução do seu pensamento sem se relevar a sua atitude no que conceme à problematização filosófica das ciências e das ilaçũes mundividenciais das filosofias que as invocaram. E como sabemos pela sua crítica de 1866 , desde muito cedo procurou encontrar a raiz metafísica do conhecimento científico, condição que considerava essencial para o colocar ao serviço da verdadeira libertação humana" (Cf. "A Metafísica Indutiva de Antero de Quental", ob. cit., p. 476).

(127) Publicado por José Bruno Carreiro, ob. cit., 2.9 vol., p. 323-324.

(128) Cartas II, ob. cit., c. 624, a Vicente Machado Faria e Maia, 1889, p. 976. 
impossibilidade de encontrar a estabilidade emocional definitiva que tanto almcjava, como virá a reconhecer na última carta que se lhe conhece a Oliveira Martins $\left({ }^{129}\right)$ : "procurava o definitivo e afinal agravei o instável e o provisório que tanto me assustava". Daf a poucos dias, esgotadas as forças para mais um e derradeiro combate, o disparo final poria termo aos desconjuntados restos de uma vida, confessadamente vivida nas fronteiras do conhecimento, entre 0 "pessimismo activo" e o "optimismo transcendental".

\section{Morte de homem}

No breve quadro que aqui deixámos, em jeito de autópsia de comportamentos, não podemos concluir outra coisa que não seja de que, naquela noite de Setembro, foi um homem cansado e doente que pôs termo à vida. Das várias demissð̃es que assumiu ao longo dos anos sempre deixou explicações. Assim aconteceu quando se desinteressou da Questão Coimbrã, quando "matou" o poeta dos Sonetos, quando se despediu da vida política. No momento em que se desinteressou da vida achou por bem não se explicar. Talvez porque já não tivesse mais nada a dizer aos vivos.

Pulverizado por tormentos de muitas contendas, orgânica e psicologicamente doente, dilacerado por fortes crises emocionais e místicas, a morte surge-lhe como um triunfo sobre todas as limitações $\left({ }^{130}\right)$. O reduto familiar onde esperava encontrar a tranquilidade de uma velhice calma e branda à espera de uma morte desejada, desmoronara-se. Oliveira Martins, o amigo e confidente, o pater afectivo estava muito longe, para que lhe pudesse sentir a mão, como em tantas outras vezes acontecera, que o puxasse de volta à esperança e a solidão amplificara-se desmedidamente. A hipocondria estimulava presságios dramáticos e Antero, $\mathrm{cm}$ alucinação depressiva, pressente que já não há futuro no seu presente. O desejo, tantas vezes proclamado, da chegada da Morte era, agora, autodeterminado por si $\left({ }^{131}\right)$. Mas não

$\left({ }^{129}\right)$ Ibidem, c. 693, a Oliveira Martins, p. 1070.

(130) V. J. Godinho, et al., "Suicídio e Tentativas de Suicídio" in Manual de Psiquiatria Clínica, dir. J. C. Dias Cordeiro, Lisboa, Fund. Calouste Gulbenkian, 1986, pp. 249-267.

${ }^{(131)}$ Neste período encontramos Antero atravessando um periodo "depressivo grave com ideação de culpa, autodesvalorização, isolamento e ansiedade, anoxcria, 
parece querer uma morte qualquer. $\mathrm{O}$ místico procura o cruzamento físico do simbólico. Isola-se na noite de $S$. Miguel e senta-se num banco do Campo de S. Francisco. No mesmo local onde, anos antes, passeara feliz e confiante, exclamando ( $\left.{ }^{132}\right)$ : "Não sei porquê, tem-me agradado esta terra e foi com certo prazer que ontem me achei a passear no Campo de S. Francisco". O Campo que fora o sinal de chamamento da terra-mãe (talvez de regresso ao ventre materno), por sinal baptizado com o nome de S. Francisco, a mais importante referência mística da mundividência pampsiquista anteriana. A Esperança, gravada em letras de bronze, por cima do banco desta última visita, sugere o Bem Universal para onde tendia a essência metafísica da teleologia anteriana.

Duvidamos que Antero tenha pensado e preparado o suicídio tendo em conta a simbólica do local. O banco onde se suicidou era, no quadro da arquitectura urbanística de Ponta Delgada, o mais recolhido e escondido de todo o Campo, aquele que lhe assegurava maiorintimidade. Mas premeditado ou não, o circunstancialismo topográficoe toponímico colocou-o no centro do seu drama existencial, do conflito do filósofo com o poeta místico que imaginara a Ordem dos Mateiros, tendo como modelo vivencial, "aquele homem incomparável e maravilhoso que foi $S$. Francisco d'Assis, quando novo, ainda, se achou quebrado e quase cego, em virtude de muitas penitências e jejuns, reconheceu que tinha errado e disse esta frase notável: 'Reconheço que pequei muito contra o meu irmão corpo'..." ( $\left.{ }^{133}\right)$.

Observando a escatologia anteriana, não se pode deixar de ser aliciado para estas particularidades simbólicas no encontro que marcou com a Morte. Também ele "ali pecou contra o seu corpo".

No entanto a mitificação da circunstância não nos deve levar à alienação do sujeito/objecto da acção sliicida, sob o risco de não reconhecermos o Homem e nos fixarmos na interpretação especulativa da simbologia que, apenas, nos permite o acesso à contextualização do caso. E o caso é o acto solitário de alguém destruído pela docnça,

emagrecimento, insónia, estados confusionais com delírio onírico, alusõoses a desejo de morte, isolamento social, idade avançada, sexo masculino sem companhia", ou seja, o conjunto quase completo de "factores de risco" de suicídio detectados por A. Barbosa e J. Dias Cordeiro, in "Urgências em Psiquiatria", ob. cit., nota supra, pp. 233-247.

(132) Cartas II, ob. cit., c. 519, a Ana de Quental, de 12 de Março de 1887, p. 827.

${ }^{(33)}$ Ibidem, c. 515, a Jaime Magalhães Lima, 20 de Janeiro de 1887, pp. 821-822. 
amargurado e deprimido, que sendo um cidadão do seu tempo, quis vivê-lo por fora, e das qualidades e fraquezas, nos ficou a memória de um Homem bom, que foi génio e foi frágil, corajoso e cobarde, combatente firme e desertor, "santo leigo" e narciso inconfesso e que, pela brusquidão da própria morte, a tornou num pedaço do mito com que, involuntariamente construiu a sua própria imortalidade.

\section{A ressurreição de Antero}

A morte não é "fenómeno ideológica e politicamente neutro. A consciência que, por ele, se legitimavam poderes sociais e políticos fez com que sectores mais politizados do operariado e do republicanismo estendessem as suas reinvidicaçðes no campo tanatologico", afirma Fernando Catroga $\left({ }^{134}\right)$. Se acrescentarmos a este conceito, a leitura antropologica, que nos propð̃e Vincent Thomas $\left({ }^{135}\right)$, para a compreensão da relação dos mortos com os vivos, e que se resume ao conjunto de motivações que exercita os vivos no desejo de evocação dos mortos, na sua veneração, no engrandecimento e embelezamento com que se sobreavalia o morto é de certa forma, presentificá-lo na memória dos vivos ou, por outras palavras, a assunção da sua imortalidade, enquanto incorporado subjectivamente na memória colectiva.

Tomando este articulado como eixo matricial da nossa reflexão, vejamos como Antero morto, retorna ao mundo dos vivos.

À beira da sepultura, Júlio Pereira de Carvalho e Costa, logo pôs a questão da urgente necessidade de se abrir uma subscrição pública para a construção de um mausoléu que perpetuasse a memória do morto $\left({ }^{136}\right)$.

O funeral foi muito concorrido e a imprensa micaelense deu-lhe grande cobertura. No préstito, no qual se incorporavam representantes dos jornais de maior prestígio na ilha, A Civilização, jornal católico de

(134) Fernando Catroga, A Militância Laica e a Descristianizaçāo da Morte, Coimbra, 1988, p. 68.

(135) Veja-se Louis Vincent-Thomas, Mort et Pouvoir, Paris, Payot, 1978.

(136) Antero de Quental teve um funeral civil. Discursaram à beira da sepultura, Aristides Moreira da Mota, reitor do liceu, Júlio Pereira da Costa, procurador régio,e Manuel Pereira de Lacerda, director do Correio Michaelense que falou em nome da imprensa local. 
inspiração jesuítica, não se fez representar. Veremos, adiante, a atitude da Igreja perante a morte de Antero.

O Correio Michaelense $\left({ }^{137}\right)$, a toda a largura da primeira página, em letras garrafais, evocava Antero de Quental, num artigo emocionado de Caetano Andrade d'Albuquerque. O Campeão Popular $\left({ }^{138}\right)$, utilizando a mesma norma gráfica, assumia a homenagem da imprensa micaelense, com reprodução de versos de Camões alusivos à Morte. $\mathrm{O}$ Diário dos Annuncios $\left({ }^{139}\right)$, no qual escrevia a destacada jornalista e escritora Alice Moderno, indefectível admiradora de Antero, concedeu largo espaço ao evento durante várias edições. Porém, logo no dia do funeral, começava a nótícia: "Temos a alma retalhada de dor", para em seguida, aludir aos acontecimentos da véspera, terminando prudentemente: "Ignora-se o que deu causa a este triste acontecimento. Anthero de Quental, viera de Lisboa estabelecer aqui residência e como se agravassem os seus males havia resolvido retirar-se já para a metropole" (Cf. nota supra).

O Diario dos Açores, o Açoriano Oriental, A Persuasão, a Gazeta da Relação $\left({ }^{140}\right)$, A Ventosa, também abordaram desenvolvidamente a questão.

Feita esta breve resenha, tomemos o Correio Michaelense e sigamo-lo, para que não multipliquemos a informação repetida.

A 24 de Setembro de $1891\left({ }^{141}\right)$, treze dias após o suicídio, noticia um conjunto de iniciativas com vista a perpetuar a memória de Antero de Quental, nomeadamente a inauguração de uma avenida com o seu nome, a construção de um busto decidida pela Câmara Municipal de Ponta Delgada $\left({ }^{142}\right)$ e, finalmente, a construção de um mausoléu no cemitério.

\footnotetext{
$\left({ }^{137}\right)$ Correio Michaelense, 3..$^{\circ}$ Anno, $\mathrm{n}^{\circ} 130,17$ de Setembro de 1891.

(138) OCampeão Popular, Anno III, n. ${ }^{\circ} 120,19$ de Setembro de 1891. Todo o jornal é dedicado à vida e morte do Poeta.

${ }^{139}$ ) Cf. Diario dos Annuncios, 7. ${ }^{\circ}$ Anno, n..$^{\circ}$ 1978, 12 de Setembro de 1891.

${ }^{(140)}$ A Persuasão e a Gazeta da Relação são propriedade de Francisco Maria Sampaio, amigo íntimo de Teófilo Braga. É, ainda Francisco Maria Supico, que sendo procurador à Junta Geral do Distrito de Ponta Delgada, pronuncia, nesta instituição, o elogio fúnebre de Antero que é confirmado como registo da Junta. Aqui, Supico, recorda que os amigos íntimos lhe chamavam "Santo Anthero", numa releitura mística desta designação. (Cf. Archivo dos Açores, XII Vol., 1892, pp. 209-210.

(141) Ibidem, 3. ${ }^{\circ}$ anno, n. $.^{\circ} 131,24$ de Setembro de 1891.

(142) A decisão camarária incumbira Oliveira Martins de procurar em Lisboa, um escultor que criasse o busto de Antero. Foi Simões de Almeida o artista indigitado. A
} 


\section{Antero de Quental}

No dia 22 de Outubro, o mesmo semanário dá conta de que a avenida foi inaugurada no dia 18 , com a presença de milhares de assistentes de "ambos os sexos" e fornece notícias das reacções à morte do homenageado em Lisboa. Informa que, da capital vão ser enviadas flores para a sepultura de Antero e que, lamentavelmente, o mausoléu não estava construído, rematando: "Será triste que comecem a chegar de fora coroas e ornatos para o túmulo sem que este esteja encomendado" $\left({ }^{143}\right)$.

Este relato sucinto deixa perceber como se vai consubstanciando na vida micaelense a presentificação de Antero, revivido em cada comemoração, ritualizado nas pompas e festas das inauguraçães, que tornam a morte aleatória e controem a imortalidade pelo reforço evocativo da memória colectiva. É, como afirma Fernando Catroga $\left({ }^{144}\right)$, "uma acentuação subjectiva e personalizada dos sinais dissimuladores da presença-ausência do corpo, a intensificação da recusa da morte através de um maior investimento moralista".

A notícia da morte de Antero, só em 23 de Setembro, é conhecida em Lisboa. O cabo telegráfico, velha aspiração da população insular, só em 1893 seria uma realidade $\left({ }^{145}\right)$. Foi o Açor, o mesmo barco no qual o poeta-filosófo pretendia viajar, que levaria a notícia do seu suicídio.

Numa indagação, por amostragem, à imprensa de Lisboa $\left({ }^{146}\right)$,

troca de correspondência entre a Câmara e Oliveira Martins, está publicada noArchivo dos A̧̧ores, XII Vol., 1892, pp. 209-210.

$\left({ }^{143}\right)$ Ibidem, n. 135,22 de Outubro de 1891.

(144) Idem, ob. cit., p. 61 .

(145) 1891 é um ano de grande agitação política nos Açores, tendo como objectivo central a reivindicação da autonomia administrativa que seria decretada em 1894, por decreto assinado por Hintze Ribeiro, durante a ditadura de João Franco. Este debate, liderado por Aristides Moreira da Mota, Caetano Andrade d'Albuquerque, Mont'Alverne Sequeira e muitos outros, resultara de um movimento, por vezes com contornos separatistas e aoqual Antero faz múltiplas referências, que se desenvolvera nas décadas anteriores, claramente influenciado pelo republicanismo de raiz federalista e municipalista, na tradição de Proudhon e Herculano, e que se fortaleceria durante a década de 80. Veja-se a este propósito: Carlos Cordeiro, "Liberalismo e Descentralização", Atlântida, vol. I, Angra do Heroísmo, IAC, 1987, pp. 23-54; Francisco Moita Flores, Republicanismo e Autonomia, Ponta Delgada, Ed. Impraçor, 1991.

(146) Foram consultados os seguintes jornais: Diário de Notícias, Diário Popular, Revolução de Setembro, A Vanguarda, Commércio de Portugal, Gazeta de Portugal e, ainda, A Nação, O Protesto Operário e a Voz do Operário. 
verificámos que os jornais, independentemente da sua postura ideológica, noticiaram com destaque o falecimento de Antero.

Porém, vai ser a imprensa operária e socialista que tutelará a apropriação ideológica, política e, como se verá, propagandística de Antero, reproduzindo-o como instrumento de combate no quadro da secularização da sociedade portuguesa. Emocionadamente sentida nos meios operários, a sua morte é de imediato articulada na doutrinação revolucionária, apresentando-o como herói mártir que, a par de José Fontana (que se suicidara em 1876) configuravam no imaginário das correntes operárias, a paternidade da Associação de Trabalhadores, assim como a doutrinação que a sustentou, projectando Antero, por entre os teorizadores da revolução proletária. O Protesto Operário $\left({ }^{147}\right)$, orgão do Partido Operário Socialista, em número totalmente dedicado a Antero de Quental, o socialista Luiz Figueiredo afirmava: "Os partidos honram os homens. Anthero merece bem, a par de José Fontana, a gratidão do proletariado".

No mesmo dia, $A$ Voz do Operário $\left({ }^{148}\right)$, em editorial, anunciava: "Morreu Anthero de Quental, um dos iniciadores, entre nos, do movimento socialista (...) à semelhança de José Fontana, buscou no suicídio o termo dos seus males".

Ora este martirológio assentava numa explicação sociológica do suicídio: a abolição de viver é justificada pela incapacidade de suportar uma sociedade, política e ideologicamente dominada pelos inimigos das classes laboriosas $\left({ }^{149}\right)$. É um Antero revolucionário, socialista, amador do Povo e da Justiça que renasce na memória operária. É um Antero reajustado às circunstâncias e aos objectivos da luta revolucionária, que em último termo assenta na redenção escatológica emancipadora do proletariado, ou seja, na construção nestc mundo, da ideia da Justiça Universal.

Por este fio condutor, vão os teorizadores socialistas e operários

$\left({ }^{147}\right)$ Ibidem, VIII Anno, n. 486, 27 de Setembro de 1891, p. 2.

(148) Ibidem, 11.9 Anno, n. ${ }^{9} 622,27$ de Sctembro de 1891, p. 1.

$\left.{ }^{(149}\right) \mathrm{O}$ artigo de Nobre França publicado n'O Protesto Operário de 27 de Setembro (Cf. nota 150) evocava Antero centrando-se no relevo dado à sua intervenção política, associava-o a uma atitude mundividencial de identificação completa com os projectos revolucionários socialistas: "O povo era o seu enlevo e a sua esperança. Amava-o como amava o seu próprio pensamento". 
ignorar a filosofia metafísica de Antero de Quental, e, dentro deste contexto, vão afirmar: "Se como o poeta francez (Vitor Hugo) não cantou a 'Justiça' a Justiça é contudo o fim ideológico da sua pocsia social" ( $\left.{ }^{150}\right)$. É o poeta das Odes Modernas apurado no cadinho das ideias de Proudhon, de Michelet, que serve à propaganda da esquerda revolucionária. Por conseguinte, que não se estranhe que a evocação poética se objective em múltiplas publicaçðes de poemas daquele livro, sendo os Sonetos Completos, o discurso místico, remetidos para discretos segundos planos.

A estratégia laicista do combate militante que marca a intervenção política dos movimentos anti-regime monárquico constitucional, particularmente republicanos e socialistas, nesta ponta final do séc. XIX, privilegia o Antero que anatematizara a Igreja catolica cujo aparato ideologico e a aliança política, sustenta o regime ao qual é atribuída a decadência da nação, portuguesa. Desta maneira, evitar a apropriação do Antero místico, pampsiquista, cristianizado, é outra das frentes de combate da propaganda operária para reivindicar o seu herói mitificado: "Noticia $O$ Século $\left({ }^{151}\right)$ que os estudantes de Coimbra vão reunir para mandarem celcbrar uma missa por alma de Anthero de Quental. Deve ser falso. A academia pode dar os mais deploráveis testemunhos do seu atraso mental. Mas o que ella não pode ć quercr conspurcar a memória do suicida glorioso, que deixa nos seus escriptos as mais brilhantes provas das suas convicçð̃es anti-religiosas" $\left({ }^{152}\right)$.

A intenção subjacente ao discurso é clara. Na mundividência laica do movimento operário e socialista, a "alma" de concepção católica morrera no momento da morte de Antero; a verdadcira alma era a "memoria do glorioso suicida" plasmada na imortalidade a que ascendera na memória do proletariado português.

É este Antero decantado, censurado, purificado na pira da Revolução anunciada, que se quer bandeira da esperança contra o medo, do novo contra o antigo. "Des deux pulsions fondamentales (...) l'espérance ct

$\left(^{150}\right)$ Cf. O Protesto Operário, VIII Anno, n. 9486 , de 27 de Setembro de 1891, p. 3.

$\left.{ }^{151}\right)$ Não foi possível confirmar a notícia no $O$ Século em virtude desta colecção, existente na Biblioteca Nacional não se encontrar disponivel. No entanto o que é importante é a atitude do jornal operário que faz a crítica.

${ }^{152}$ ) Cf. $O$ Protesto Operário, VIII Anno, n. 986,4 de Outubro de 1891, p. 1. Sublinhados nossos. 
la peur, on peut dire que la Revolution a laissé le double héritage. Avec uns elle a laissé la peur (...) aux autres, elle a laissé l'espérance, l'idée que l'on peut changer le monde" $\left({ }^{153}\right)$. Desta forma devemos compreender outras iniciativas assumidas pelos dirigentes socialistas e operários. Uma comissão constiturda, entre outros por Nobre França, Canuto Rosa Viterbo e Sousa, Albino Morais, Azedo Gneco $\left({ }^{154}\right)$, assumiu o encargo de "mandar uma mensagem de sentimentos à famflia do finado, assignada por todos quantos acceitam o grande Ideal de Justiça que liga indelevelmente o philosopho das Odes Modernas e dos Sonetos", mandar pôr no túmulo de Antero de Quental "uma côroa de bronze, com uma dedicatória dos socialistas". Pretendeu, ainda, levar a efeito a publicação de uma colectânea "contendo todos os escriptos socialistas de Anthero de Quental",e, finalmente, organizar conferências em que se reflicta sobre a influência na sociedade, da sua intervenção política e intelectual, porque "foi a Justiça, o Bem, o Progresso Social" o grande e único ideal que animou Anthero toda a sua vida".

Durante semanas a imprensa operária fez ressoar o eco das reacçð̃es de pesar. Dezenas de associaçð̃es de classe e outras agremiaçð̃es manifestaram-se em múltiplas expressð̃es de homenagem e de evocação à memória de Antero de Quental ( $\left.{ }^{155}\right)$.

A presentificação de Antero recondu-lo ao mundo dos vivos e o surto evocativo e homenageante completa-se pela exibição da sua expressão viva. A fotografia na campa dos mortos tem essa significação ilusória do prolongamento da vida. Sepultado em Ponta Delgada, longe do centro da disputa política, torna-se necessário que o ressurgimento e incorporação subjectiva na memória proletária, perpetue esse sinal de vida. É assim, que devemos entender a venda de fotografias de Antero de Quental, incrustadas em cartão e que $O$ Protesto Operário fomenta $\left({ }^{156}\right)$.

${ }^{153}$ ) Cf. Michel Vovelle, "La Mentalité Révolutionnaire", Revista de História das Ideias, n. 9 9, 2. ${ }^{\circ}$ tomo, Coimbra, 1987, pp. 425-437. c. 2.

${ }^{(144)}$ Cf. $O$ Protesto Operário, VIII Anno, n. ${ }^{9} 486,4$ de Outubro de 1891, p. 3,

(155) A Voz do Operário durante meses, em todos os números, faz referências a Antero, noticiando as homenagens e iniciativas realizadas por associações de trabalhadores ou publicando poemas das Odes Modernas.

$\left.{ }^{156}\right)$ Cf. Ibidem, VIII Anno, n.9 486, 4 de Outubro de 1891, p. 3, c. 3. 
Porém, a tutela definitiva da imortalidade projectada num quadro teleológico de libertação revolucionária, por parte do movimento operário, era aparentc. Se o quisera agarrar como um referencial congregador das potencialidades afectivas e ideológicas do grupo, com vista à prossecução de objectivos políticos, o carácter imediatista do combate político e a própria fragilidade das forças de esquerda não tiveram (ou não soubcram) a possibilidade de monopolizar a sobrevivência da sua memória, num contexto mundividencial essencialmente laico e revolucionário.

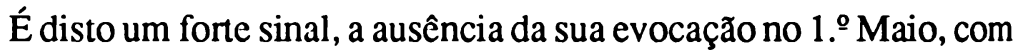
a relevância atribuŕda a José Fontana e a Sara de Matos, que no ano de 1892 morrera no Convento das Trinas $\left({ }^{157}\right)$. Por outro lado, tendo em conta a forte componente tanatológica nas comemoraçóes do $1 .^{9} \mathrm{de}$ Maio, em finais do século passado, traduzidas em romarias às sepulturas dos heróis do movimento operário, a ausência do cadáver inumado de Antero num cemitério de Lisboa, não fomentou o ritual de sobrevivência.

A Igreja católica que de início tratou com alguma indifcrença, e até desprezo $\left({ }^{158}\right)$, a sua morte, iria, perdido o fôlcgo operário, paulatina c inexoravelmente assumir a vida e obra do poeta-filosofo, integrando-o no scu espólio espiritual.

Como dissémos, inicialmente a posição que assumem é pautada pela tibieza. Antero não cra, de facto, um homem da Igreja católica, da qual se afastara definitivamente na adolescência. $O$ misticismo de raiz cristã, estruturado a partir do pampsiquismo tinha como referencial $S$. Francisco d'Assis que o suicidado não considerava integrado na Igreja tridentina. Depois o próprio suicídio o colocava fora da Igreja católica, por imperativos do direito canónico.

Assim, a notícia é dada pclos jornais católicos, mas a morte é explicada pelo facto de Antero ter deixado de trilhar os caminhos da Fé. É bem claro do distanciamento a que aludimos, a notícia que $A$ Nação $\left({ }^{159}\right)$ publicou c da qual apresentamos este cxcerto: "descendo

$\left.{ }^{157}\right)$ Sobre o significado do $1 .^{9}$ de Maio, veja-se de Fernando Catroga, ob. cit., pp. 861-890, e, ainda, do mesmo autor "Os Primórdios do $1 .^{2}$ de Maio em Portugal, Fcsta, Luto, Luta", Revista dellistória das Ideias, vol. 11, Coimbra, 1989, pp. 445-499.

${ }^{158}$ Cf. nola 159.

( $\left.{ }^{159}\right)$ Cf. $\Lambda$ Naçāo, XLVI Anno, n. ${ }^{9} 11$ 541, 26 de Setembro de 1891, p. 1. Sublinhado nosso. 
das dulcíssimas regiōes da poesia, à loucura sceptica e morbida (...) despedaçou o cerebelo com duas balas de rewolver (...) Não veneramos os ideaes por que aquelles dois últimos gigantes do pensamento [refere-se a Camilo e a Antero] batalhavam, pois constituíam a negação do que é fundamental para a regular e fecunda evolução das sociedades modernas a Igreja Catholica...".

Portanto, nem a vida nem a morte (por suicídio) possibilitavam, por intenção expressa da Igreja, o ingresso na comunidade católica que preconiza repouso eterno "entre o esplendor da luz perpétua".

Em Janeiro de 1892, o capelão da Santa Casa da Misericórdia à qual pertencia o Hospital de Ponta Delgada, o padre Januário Filomeno Velosa escrevia o assento de óbito, começando aí a derreter o gelo inicial da relação da Igreja católica com o suicidado. É, quanto a nós, um documento notável que merccerá, noutro momento, um estudo mais profundo para a compreensão da apropriação de Antero no quadro da escatologia católica. José Bruno Carreiro $\left({ }^{160}\right)$ publica-o na integra e o remate do assento é significativo. Depois de recordar o funeral civil e aqueles que discursaram junto do túmulo, "com frases sentimentais", conclui: "E eu, silencioso, dizia: A Dcus protector da inocência. Descansa em paz. 'Dorme o teu sono coração liberto. Dorme na mão de Deus eternamente' ".

A lógica discursiva está invertida. Se a cotejarmos com o discurso operário, a verdadeira imortalidade é a da alma e a memória colectiva é secundarizada neste movimento telcológico. Por outro lado, a citação de versos dos Sonetos (agora são as Odes Modernas subalternizadas) é a fresta que abre e pcla qual o Antero cristão, budista, mctafísico e místico vai ser manipulado para os objectivos idcológicos e de propaganda da Igreja católica. Porém, ainda está longe o tempo da leitura integralista de António Sardinha e o seu estudo de Antero, assim como de seus sucedâneos $\left({ }^{161}\right)$, num infindável cortejo de anteranistas de um "Antero católico".

Por entre os diversos desejos e movimentos de apropriação, vai aparecer o In Memoriam, incentivado por Eça de Qucirós.

Construída pela complição de textos escritos por amigos pessoais

$\left({ }^{160}\right)$ Apud Ibidem, $2 .^{\circ}$ vol., pp. 325-326.

${ }^{(61)} \mathrm{Na}$ linha da teorética de raiz católica, interpretativa de Antero, surgem o 
do homenageado, onde pontificam alguns dos nomes de maior destaque da Geração de 70, coetâneos militantes da mundividência laica, abriram para a imortalidade as portas da sacralização de Antero de Quental.

Particularmente o artigo de Eça é a objectivação canonizante da imortalidade do Antero-homem. A liturgia ć́vica que preside à elaboração do In Memoriam, exprime "o consenso social mediante representações simbólicas capazes de darem à existência subjectiva e social um sentido que ultrapasse os limites da morte individual e do relativismo histórico" $\left.{ }^{162}\right)$.

Resta-nos concluir que a gestão da sua morte e da construção complexa da imortalidade, quer através da perpetuação na memória colectiva quer através dodiscursoescatológico-religioso, se transformou num epifenomeno, sob o qual se estruturou a bem gerida imortalidade da sua própria Geração.

Como referimos, logo no início deste trabalho, é difícil surpreender o Homem que se esconde por detrás desta nebulosa mitificante e, em alguns casos, mistificadora. As páginas dos livros garantiram-lhe a eternidade do discurso poético, filosófico e político. Do corpo restam cinzas e algumas peças ósseas que, possivelmente, tal como as exumaram, nem sejam de Antero. Através desta autópsia procurámos encontrar-lhe a morte e, por esta, entender a vida, como se a vitoria de "Tanathos" sobre "Éros", conduzisse ao renascer do derrotado. Talvez, por isto, cem anos depois do disparo fatídico, continuamos a sedimentar, no mesmo ritual litúrgico, a perpetuidade de Antero com motivação idêntica àquela que tiveram os seus amigos. Porque foi "Um Génio" e, na memoria nos ficou gravado como "um Santo" profano.

Cardeal Cerejeira, P. Moreira das Neves, os Jesuítas Agostinho Veloso, Lúcio Craveiro da Silva e, talvez sob influência deste, Miller Guerra. O conhecido jomalista António Valdemar realizou investigações sobre esta matéria, formecendo informações que agradecemos.

(162) Fernando Catroga, A Militância Laica..., ob. cit, p. 1020. 


\section{As mortes de Antero de Quental}

Fontes e Bibliografia

I - Fontes Manuscritas

Hospital de Ponta Delgada:

Livro de Registo de Doentes de 1891 (2.. Semestre).

Cemitério de S. Joaquim:

Livro de Títulos e Jazigos do Cemitério Municipal de S. Joaquim d'esta cidade, fls. 10 e 10 verso.

Registo de inumaçōes, Março de 1891, mês de Setembro.

II - Fontes Impressas

A) De Antero de Quental:

Cartas, Org., int. e notas de Ana Maria Almeida Martins, 2 vols., Lisboa, Ed. Comunicação, 1989.

Causas da Decadência dos Povos Peninsulares, Lisboa, Ed. Ulmeiro, 1970. Odes Modernas, Lisboa, Ed. Ulmeiro, 1983.

Prosas, 3 vols., Coimbra, Imprensa da Universidade, 1923, 1926, 1931.

Tendências Gerais da Filosofia na Segunda Metade do Século XIX, Lisboa, Ed. Comunicação, 1988.

Sonetos Completos publicados por J. P. de Oliveira Martins, Porto, Livraria Portuense de Lopes e C. ${ }^{\circledR}$ Editores, 1886.

B) Fontes Impressas Directas - Livros e Publicaçðes Periódicas:

Anthero de Quental, In Memoriam, Porto, Mathieu Lugan, 1896.

Correspondência de J. P. Oliveira Martins, Editada por Francisco Assis

Oliveira Martins, Lisboa, Parceria António Maria Pereira, 1926.

Archivo dos Açores, Vol. XII, Ponta Delgada, 1892.

Jornais:

De Ponta Delgada:

Açoriano Oriental (0), 1891.

Correio Michaelense, 1891, 1892.

Diário dos Açores, 1891, 1924.

Diário dos Annuncios, 1891.

Persuasão (A), 1891.

Ventosa (A), 1981.

De Lisboa:

Commercio de Portugal (0), 1891.

Diario de Notícias, 1891.

Diario Popular, 1891. 
Nação, (A), 1891.

Protesto Operário (0), 1891, 1892.

Revolução de Setembro (A), 1891.

Vanguarda (A), 1891.

Voz do Operário (A), 1891, 1892.

III - Obras Consultadas:

BRAZETTE, Maria Manuela - "Viver na Esperança - Perder a Esperança" in Estados-Limite, IV Seminário de Psicologia e Psicopatologia Clínica, Lisboa, Hosp. Miguel Bombarda, 1989, pp. 23-35.

CARREIRO, José Bruno-Antero de Quental, Subsídios Paraa SuaBiografia, P. Delgada, Inst. Cult. P. Delgada, 1948, 2 vols.

CARVALHO, Joaquim de - Obra Completa de Joaquim de Carvalho, Vol. IV, Lisboa, Fund. Calouste Gulbenkian, s/d.

CATROGA, Fernando-"A Ideia de Evoluçãoem Antero de Quental", Biblos, vol. 56, Coimbra, 1980, pp. 357-388.

O Problema Político em Antero de Quental. Um confronto com Oliveira Martins, Coimbra, Centro de História da Sociedade e da Cultura da Univ. de Coimbra, 1981.

Filosofia e Sociologia-AIdeia Anteriana de Socialismo, Coimbra, 1982, Sep. da Revista Vértice, vol. XIII, n. 948.

"A Metafísica Indutiva de Antero de Quental", Biblos Vol. LXI, Coimbra, 1985, pp. 472-507.

A Militância Laica e a Descristianização da Morte em Portugal, 1865-1911, Coimbra, 1988, 2 vols.

CORDEIRO, Carlos - "Liberalismo e Descentralização", Atlântida, Vol. I. Angra do Heroísmo, IAC, 1987.

CORDEIRO, J. C. Dias - Manual de Psiquiatria Clínica, Lisboa, Fund. Calouste Gulbenkian, s/d.

CIDADE, Hernâni - Antero de Quental, 2. ed., Lisboa, Ed. Presença, 1988. FIGUEIREDO, Fidelino - Antero de Quental. A Sua Psicologia, a Sua Filosofia, a Sua Arte, Lisboa, 1909.

FLORES, Francisco Moita - Republicanismo e Autonomia, P. Delgada, Impraçor, 1991.

FOUCAULT, Michel - Les mots et les choses, Paris, Ed. Gallimard, 1986.

GURVITCH, G. - Tratado de Sociologia, Lisboa, Iniciativas Editoriais, 2 vols., 1968.

GUERRA, Miller - "A Reforma Pombalina dos Estudos Médicos", in Pombal 
Revisitado, Lisboa, Ed. Estampa, vol. I, pp. 189-207.

GUILLON, Claude - Suicídio, Modo de Usar, Lisboa, Ed. Antígona, 1990.

GOLDEY, P. - "A Boa Morte: Salvação Pessoal e Identidade Comunitária", in AMorte no Portugal Contemporâneo, Lisboa, Ed. Querco, pp. 189-209.

HOMEM, Amadeu Carvalho-AIdeia Republicana emPortugal. O Contributo de Téfilo Braga, Coimbra, Ed. Minerva, 1989.

LOURENÇO, Eduardo - "Antero ou o Socialismo como Utopia", in Poesia e Metafisica. Camöes. Antero. Pessoa, Lisboa, ed. Sá da Costa, 1983, pp. 147-153.

MEDINA, João-Oh! a República!... , Lisboa, INIC, 1990.

MELO, Lúcia da Costa - Ensaio de uma Perspectiva Surrealista na Vida e Obra de Antero de Quental, P. Delgada, Inst. Cult. P. Delgada, 1978.

MANNHEIM, Hermann -Criminologia Comparada, Lisboa, Fund. Calouste Gulbenkian, 2 vols.

MORIN, Edgar - $O$ Homem e a Morte, Lisboa, Ed. Europa-América, s/d.

MORON, Pierre - $O$ Suicídio, Lisboa, Ed. Europa-América, s/d.

ORTEGA Y GASSET - En Torno de Galileo, Madrid, R. Occidente, 1967.

PIRES, António B. Machado - A Ideia de Decadência na Geração de 70, Ponta Delgada, Instituto Universitário dos Açores, 1980.

SANTOS, Jorge Costa-A Morgue e a Morte, Sep. Revista Povos e Culturas, n. ${ }^{2} 3,1988$.

SARAIVA, António José - A Tertúlia Ocidental, Lisboa, Gradiva, 1990.

SÁ, Victor - Ensaios IV, Lisboa, Sá da Costa, 1981.

SERRÃO, Joel - "Antero de Quental" in Dicionário História de Portugal, Porto, Livraria Figueirinhas, vol. V, pp. 213-218.

"Do Pensamento Socio-Político de Antero de Quental (1868-1873)", in $O$ Século XIX em Portugal, Lisboa, Ed. Presença/GIS, 1980, pp. 373-391.

"Do Pensamento Socio-Político de Antero de Quental (1873-1889)" in Cultura-História e Filosofia, Lisboa, INIC, Univ. Nova de Lisboa, pp. 6-8. Liberalismo, Socialismo, Republicanismo, Antologia de Pensamento Político Português, 2.! ed., Lisboa, Livros Horizonte, 1979.

SIMŌES, João Gaspar - A Geração de 70. Alguns Tópicos Para a Sua História, Lisboa, Ed. Inquérito, Cad. Cult.

THOMAS, L. Vincent - Anthropologie de la Mort, Paris, Ed. Payot, 1975.

Le Cadavre, de la Biologie àl'Anthropologie, Bruxelles, Ed. Complexe, 1980. Mort et Pouvoir, Paris, Payot, 1978.

VOVELLE, Michel - "La Mentalité Revolutionnaire", Revista de História das Ideias, n. ${ }^{9} 9,2 .{ }^{9}$ tomo, Coimbra, 1987, pp. 425-437. 
La Mort et l'Occident. De 1300 à nous jours, Paris, Gallimard, 1983.

\begin{abstract}
APÊNDICE
Devido às muitas dúvidas que nos foram surgindo ao longo da investigação realizada em torno das causas do suicídio de Antero de Quental, recolhemos junto de dois peritos médicos qualificados, os irmãos, Dr. Jorge Costa Santos e Dr. Francisco Costa Santos, ambos do Instituto de Medicina Legal de Lisboa, entrevistas sobre as doenças e morte do poeta-filosofo.

Porque ambos estudam com particular interesse esta problemática, embora em especialidades diferentes, pedimos-lhe os respectivos pareceres numa linguagem simples, o mais descodificado possívcl em termos de qualquer leitor compreender o sentido das respostas sem a necessidade de grandes conhecimentos da semiologia médico-científica.

Reconstituição do suicídio de Antero de Quental, segundo a opinião médico-legal de Francisco Costa Santos que, definindo a asfixia como causa de morte, exclui, simultaneamente, a hipótese do segundo tiro. Por concordarmos com esta análise, aqui apresentamos com a utilização de modelos desenhados.
\end{abstract}




\section{Entrevista FRANCISCO COSTA SANTOS *}

$\mathrm{P}$ - Antero de Quental suicidou-se há um século com dois tiros na boca. É um suicídio singular...

$\mathrm{R}$ - Singular e, quanto a mim, romantizado, quase diria ficcionado. Como médico-legista posso dizer que a singularidade do suicídio assenta mais nas explicaçð̃es apresentadas, do que no facto de estarmos perante uma morte violenta, tão normal no século passado como hoje. O suicídio é um problema social e existencial que pela carga agressiva implícita continua a concitar a atenção dos especialistas e do grande público em geral. Ao médico-legista cabe fundamentalmente caracterizar o circunstancialismo em que a morte ocorreu, não só pela informação que acompanha o cadáver, mas, sobretudo, pelas conclusð̃es que resultam do seu exame autóptico. Como sabe Antero de Quental não foi autopsiado, acto médico vulgar para a época e que poderia, caso tivesse sido realizada, ter logo à partida posto termo às especulaçð̃es posteriores.

P - Mont'Alverne Sequeira, médico que acorre, afirma que ele realizou dois tiros na boca.

$\mathrm{R}$ - Não sei qual a fundamentação de Mont'Alverne Sequeira para produzir tal afirmação. Como disse, Antero de Quental não foi autopsiado, e os relatos recolhidos por Bruno Carreiro e outros que foram publicados tendo por base testemunhos de pessoas que viram Antero ou na fase agónica ou já morto, não permitem concluir que ele disparou contra o palato ósseo duas vezes.

$\mathrm{P}$ - Em que dados se sustenta para emitir esse juizo?

$\mathrm{R}$ - Em primeiro lugar, é preciso esclarecer que é sob reserva que avanço este prognóstico. Não vi o cadáver, ou o que dele resta, para uma conclusão mais precisa, pelo que as minhas afirmações são sustentadas pela crítica dos documentos que acima aludi, e não por uma peritagem médico-legal. Posto isto, penso que Mont'Alverne Sequeira fez afirmações precipitadas e que carecem de suporte cientifico. Repare, ninguém ouviu os dois tiros. O único testemunho que afirma Lisboa.

* Assistente da Faculdade de Medicina de Lisboa, Médico-Legista do S.M.L. de 
tal facto é um polícia, que se encontra a algumas centenas de metros do local da ocorrência e, mesmo assim tem a cautela de afirmar que ouviu "confusamente". Dois tiros numa noite sem barulho, num largo praticamente fechado, perto do hospital onde, a essa hora a vida continua com certa actividade, e ninguém, mais ninguém ouve, nem os estrondos das explosões e os respectivos ecos? É preciso ser mais prudente, no que respeita a esta circunstância. Depois, os relatos que nos chegaram, informam que Antero tem uma ferida de saída de projéctil nos ossos do nariz, abaixo da articulação com o osso frontal. E o segundo projéctil onde está? Na cabeça? Mont'Alverne Sequeira fez a exumação décadas depois, não o refere, o que é pouco natural, para um médico que assistira aos últimos momentos do exumado.

$\mathrm{P}$-Então, na sua opinião, Antero de Quental morreu de um tiro que disparou contra si?

$\mathrm{R}$ - Nem isso. Antero de Quental morre das complicações que ocorrem depois de ter disparado esse tiro. Vejamos: a mais verosímil hipótese é de que Antero tenha apenas disparadoum tiro. Pela trajectória do projéctil e atendendo à anatomia do pulso, deverá ter empunhado a arma cm posição invertida, encostou o cano do revólver ao palatoósseo e disparou. A bala entra pelo palato, com um sentido de cima para baixo, atravessa a cara, pela parte interior e sai pelos ossos do nariz, abaixo da articulação com o osso frontal, isto é, numa forma mais simples, sai entre os olhos. As lesões provocadas são graves. A explosão da pólvora queima-lhe as mucosas da boca e a destruição de tecidos ósscos, cartilagens e moles localizam-se em regioes fundamentais para a continuação da vida, isto é, foram lesionadas as vias respiratórias principais, a boca e o nariz. O próprio impacto do disparo, por reacção, ter-lhe-à tirado a arma da boca, e a hemorragia, devido à posição em que o corpo se encontra - recorde-se que Antero ficou sentado - ainda que desenvolvendo-se para as zonas posteriores da cabeça, e daí sangrar abundantemente pela boca e pelo nariz, quando é colocado em decúbito dorsal, graças à aç̧ão da gravidade, dirige-se para as regiões postcriorcs, afectando a tracto esogástrico e o traqueo-brônquico. Esta complicação é típica do síndrome asfíxico. Ao inspirar, aspira sangue que invadindo as vias respiratorias inferiores vai provocar a morte por asfixia. Aliás, é na confirmação deste prognóstico que apontam os testemunhos de um Antero que apresenta movimentos 
descoordenados de respiração a que correspondem movimentos cambaleantes da cabeça e que, conforme se aproxima o estado terminal, entra em convulsð̃es "que dois homens não conseguem segurá-lo". Quanto a nós, Antero de Quental morre de asfixia, embora asfixiado no seu proprio sangue.

P - Mas Mont'Alverne Sequeira afirma que Antero lhe indicou, levantando dois dedos, que foram dois e não um tiro...

$\mathbf{R}$-Pensamos que sobrevalorizou tal gesto. De facto, o gesto da mão poderia ter indicado dois disparos, mas estamos em crer que foi um gesto reflexo sem qualquersignificação consciente. Aliás, Mont'Alverne Sequeira chegou junto do moribundo bastante tarde, mais ou menos vinte minutos depois do evento. Esse tempo é suficiente para provocar um estado de asfixia grave, e assim foi que pouco mais de meia hora depois, Antero morreria. À crescente asfixia, durante a fase agónica, corresponde uma diminuição progressiva da capacidade consciente. Os gestos tornam-se descoordenados, as convulsões ganham maior evidência e, por fim, advém a morte. $O$ paradoxo de toda esta situação é que hoje, cem anos depois, o aparato técnico-cirúrgico e o conhecimento médico, teriam evitado a morte de Antero de Quental. Tão perto do hospital, quase dá a ideia de que dispara ali para scr socorrido, hoje, provocando a aspiração do sangue e com recurso cirúrgico, reconstituindo os tecidos destruídos, poderia não ter ocorrido a morte, $o$ que não significa que cle não atentasse outra vez contra a própria vida.

$\mathrm{P}$ - Anos depois, outro médico, filho do seu amigo José Bensaúde diagnostica-lhe "uma estenose do piloro".

$\mathrm{R}$-É possível. Repare quando ele morreu apenas lhe encontraram um pacote de bismuto, produto que na época, e ainda hoje, se destina à terapia de doenças de estômago. A estenose é, em linguagem menos científica, uma espécie de calo que aparece depois de ter cicatrizado deficientemente uma lesão, nomeadamente uma úlcera do estômago. Esse "calo" apertando-lhe o piloro, válvula que liga o estômago ao duodeno poderá explicar as dificuldades digestivas que ele tinha na última fase da vida.

$\mathrm{P}$ - Antero morto com um tiro, exumado depois sem que lhe seja encontrado o segundo projéctil, vai de encontro ao seu ponto de vista. 
$\mathrm{R}$-É verdade. Mas deixe-me dizer-lhe que também tenho muitas dúvidas no que respeita a essa exumação. Não posso crer, sem mais nenhuma explicação, que do esqueleto de Antero tenham restado uma pequena porção de peças ósseas, como consta do auto de exumação que Bruno Carreiro publicou. A identificação, em primeirolugaré imprecisa. O facto de se lhe ter descoberto pedaços de roupa preta e os sapatos não é garantia de identificação. Naquele tempo, e ainda hoje em algumas partes do país, os cadáveres das famílias abastadas vão para o caixão vestidos de preto, com traje de gala. Antero foi assim vestido, e também deverão ter ido da mesma forma, o pai e o avô que estão inumados no mesmo jazigo. Quem nos garante que não são peças de tecido de indumentárias de outros mortos? No que respeita aos sapatos, esta peça é a de menos importância na composição geral do embelezamento do cadáver, e como pode Mont'Alverne Sequeira ter a certeza de que cram sapatos de Antero? Aliás, tendo em conta que o registo que fazem da sua compleição física, os sapatos são capazes de serem um pouco pequenos para o pé que ele deveria ter. Porém, comolhe disse, tudo isto são hipóteses de trabalho que uma exumação com o respectivo cstudo osteológico poria a claro. Até para pôr em evidência essa surpresa pcla cscassez de ossos recolhidos. Havendo esquelctos que, no essencial, continuam em bom estado passados séculos, tendo $\mathrm{cm}$ conta que as condições de humidade e corruptabilidade dos solos sendo idêntica para os cadáveres inumados na mesma zona, não produz tal deterioração em outras ossadas aí exumadas, é bem possível que a identificação de Antero, no conjunto da família que ali foi enterrada, continuc por fazer. 


\section{Entrevista JORGE COSTA SANTOS*}

P - A "Nosographia de Antero", estudo que Sousa Martins lhe dedicou, continua a ser um trabalho polémico.

$R$ - É verdade. E isto, em parte, porque Sousa Martins não era um psiquiatra, ou, como então se dizia, um alienista. A extraordinária actividade profissional por ele desenvolvida inscrevia-se sobretudo na área que hoje corresponde à medicina interna, ainda que, a época, e dada a quase completa ausência de especialidades médicas razoavelmente diferenciadas, fosse solicitado para as mais diversas situações clínicas. Sousa Martins era sobretudo um médico generalista, dotado de excepcionais qualidades clínicas.

O facto de ter escrito a "Nosographia", a despeito do conteúdo polémico e da sua forma algo deslocada para um "In Memoriam", deverá ser entendido como uma homenagem póstuma à figura de Antero, com quem privou e a quem, ocasionalmente, chegou a prestar assistência médica.

Assinale-se, todavia, que o sofrimento psicológico de Antero o havia levado, em Paris, a recorrer aos cuidados de Charcot, um dos mais reputados alienistas da época, que então lhe diagnosticou uma "histeria". Embora esta categoria diagnostica persista na nosologia psiquiátrica, a verdade é que o seu alcance se viria a restringir progressivamente com a evolução dos conhecimentos neste domínio especializado da medicina.

No entanto, Sousa Martins, que, repetimos, não era um alienista, evidencia nesse seu estudo, a par de uma erudição médica notável, um estreito conhecimento das doutrinas psiquiátricas de pendor organicista então dominantes.

O conteúdo polémico que hoje reconhecemos na "Nosographia", resulta, em meu entender, da conjugação de dois factores: por um lado, da ausência de formação psiquiátrica específica do autor e, por outro - seguramente o mais importante-, dos efeitos erosivos do tempo, que se encarregariam de demonstrar a falta de fundamentação científica das teorias da degenerescência em que Sousa Martins baseia o essencial da sua análise.

* Director do Serviço de Psiquiatria Forense do Instituto de Medicina Legal de Lishoa e Assistente da Faculdade de Medicina de Lisboa. 
P - Vai afirmar que Antero é produto de uma degenerescência em virtude de ter sido gerado em condições de consanguinidade...

$\mathbf{R}$-Como disse antes, isso resulta sobretudo da enorme repercussão que tiveram, na época, as teorias da degenerescência de Morel e Magnan, que influenciaram não poucos psiquiatras, incluindo alguns reputados especialistas, como Lombroso, que sobre elas edificaria a sua doutrina do delinquente nato. Mas se Sousa Martins não pode ser criticado pclo facto das suas referências teóricas terem perdido, entretanto, a credibilidade científica, já é mais difícil encontrar uma explicação razoável para a ligeireza com que ele se reporta à hereditariedade de Antero, utilizando dados que, já à data, se sabia não serem verdadeiros.

Neste sentido, a sua análise, onde transparece um certo exibicionismo fabulador, é construída a partir de falsos pressupostos, designadamente da consanguinidade próxima dos pais, que, tudo leva a crer, nunca terá existido, e adaptada ao quadro geral da degenerescência tal como havia sido descrito por Morel e Magnan.

A ideia com que se fica da leitura da "Nosographia" é um pouco como se Sousa Martins, porque conhecesse antecipadamente o puzzle e acreditasse que o perfil psicopatológico de Antero se lhe adequava, se tivesse dado ao cuidado de talhar algumas peças, isto é, certos estigmas físicos e psicologicos, que lhe permitissem construir a fisionomia do degenerado, tal esta havia sido cientificamente descrita.

Acrescente-sc, todavia, que, à luz dos conhecimentos actuais, não se pode excluir a possibilidade da psicopatologia de Antero ter resultado, pelo menos em parte, de uma certa influência hereditária, mas de outro tipo, isto é, relacionada com a provável existência de distúrbios afectivos em parentes do $1 . \circ$ grau.

P - Depois de Sousa Martins, outros médicos procederam a diagnósticos psicopatológicos retrospectivos de Antero de Quental, nomeadamente Miller Guerra, que nos inícios da década de 60 vai defender que ele padecia de uma psicose maníaco-depressiva.

$\mathbf{R}$ - Assim foi de facto, e penso que a contribuição do Prof. Miller Guerra, um dos mais destacados neurologistas portugueses - ou, se quisermos, um neuropsiquiatra, na antiga acepção do termo-, constitui uma peça importante para o esclarecimento do quadro psicopatológico de que sofria Antero. 
$\mathrm{P}-\mathrm{E}$ outros médicos vieram a repensar as doenças de Antero. Afinal de que padecia Antero?

$\mathbf{R}$-É difícil responder-lhe de uma forma definitiva, porquanto não conheço suficientemente a sua biografia nem a totalidade da sua obra. Ainda assim, o conteúdo da sua poesia e das cartas que nos legou deixa transparecer um conjunto de sintomas que se ajusta ao que hoje designamos, em psiquiatria, por distúrbio afectivo maior do tipo bipolar, diagnóstico que corresponde, na classificação tradicional, à psicose maníaco-depressiva, a que se referiu o Prof. Guerra.

Também é verdade que, entretanto, surgiram outras opinið̃es médicas que correspondem a leituras de inspiração e interpretação diferentes. Todavia, tanto quanto sei, nenhuma delas põe em causa a existência de fenomenos psicopatologicos na vida e obra de Antero, sugerindo, isso sim, outras hipóteses de diagnóstico.

Pela minha parte, com a salvaguarda feita anteriormente, inclino-me, pelo que conheço da sua obra, para a existência de um distúrbio afectivo ciclotímico, sem excluir evidentemente que este possa preencher os critérios de diagnóstico do distúrbio afectivo maior a que já me referi.

Limito-me a assinalar, sem que isto pretenda substituir um qualquer esforço de análise mais profundo e rigoroso, a alternância periódica do humor e do ritmo de vida de Antero, que ressalta sobretudo das suas cartas. Af́ se identificam de forma iniludível, as oscilaçð̃es entre estados depressivos, dominados por uma atitude pessimista perante a vida, pelo humor triste, o desânimo, o desinteresse pelo que o rodeava, a fadiga fácil e a insónia persistente de que se queixava tão amiúde, e outras fases onde, pelo contrário, se reconhecem uma actividade intelectual intensa, uma agitação febril, uma energia aparentemente inesgotável e a ausência de queixas de fadiga, sintomas que poderão corresponder ao que designamos por episódios hipomaníacos.

P - Um quadro clínico desta natureza pode conduzir ao suicídio?

$\mathrm{R}$ - É evidente que sim. Aliás, é bem conhecido dos médicos em geral o maior risco de suić́dio dos doentes que sofrem de distúrbios afectivos. Dados estatísticos recentes indicam que cerca de $15 \%$ dos pacientes que sofrem de depressões de uma certa gravidade se suicidam. Em termos estatísticos, Antero, para além do distúrbio afectivo, possufa ainda outros factores consideráveis de risco de suić́dio, como, por 
exemplo, a idade vizinha dos cinquenta anos, o facto de ser solteiro e não ter referência afectiva próxima e o isolamento voluntário a que se havia remetido durante a última fase da sua vida.

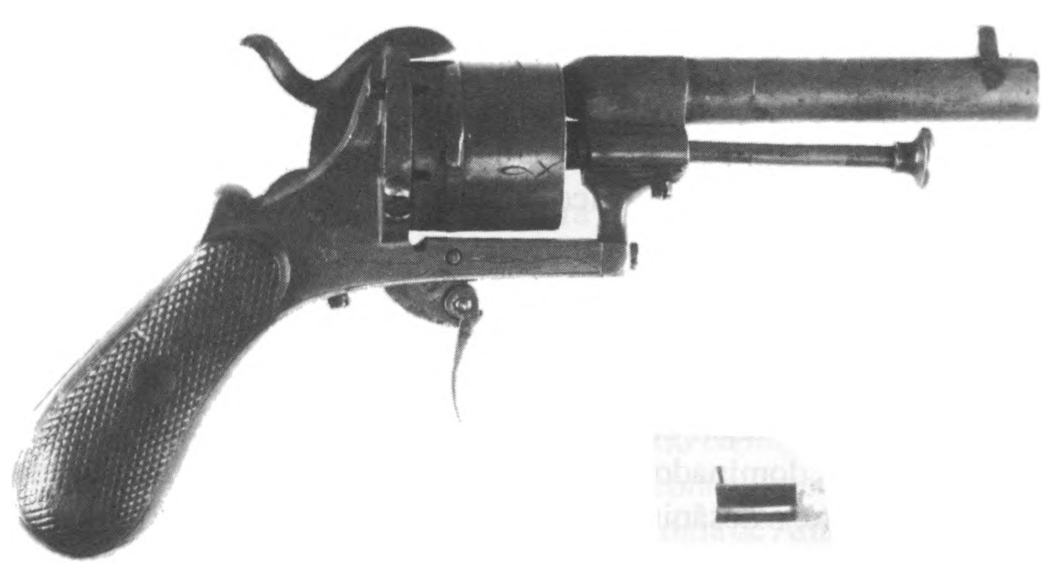

Revólver do modelo Lefaucheux, do mesmo tipo daquele com que Antero de Quental se suicidou. (Arma do Museu do LPC) 


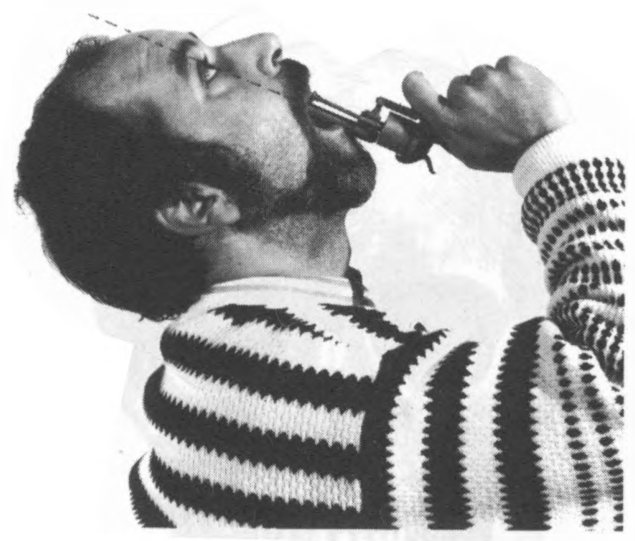

A hipótese proposta por Mont'Alverne Sequeira. Como se vê, existe a forte possibilidade do projéctil entrar no frontal o que contradiz o facto de ter saído pelos ossos do dorso do nariz.

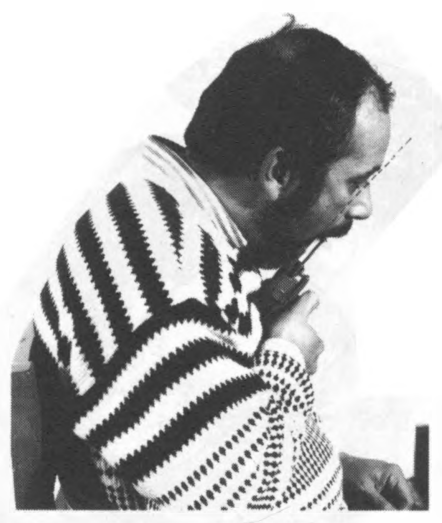

A hipótese de Francisco Costa Santos. O disparo é realizado com o polegar da mão direita e o corpo dobrado para a frente. A munição atinge o crâneo. 


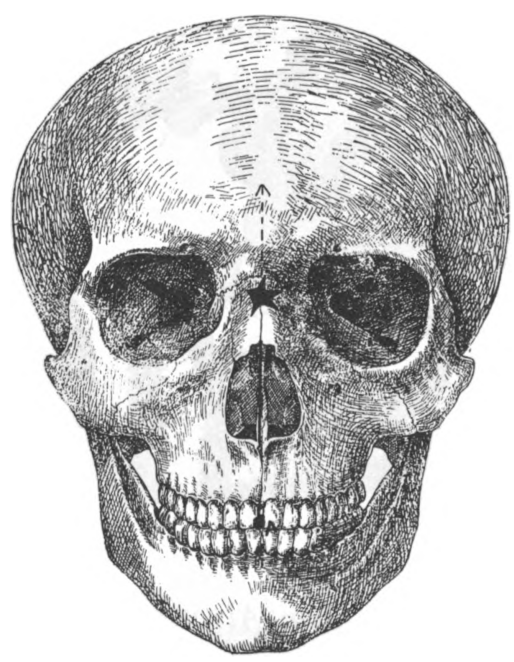

Modelo visto de frente. $\boldsymbol{A}$ indica a zona de disparo. $O$ traço contínuo mostra a trajectória interior da bala. $\boldsymbol{B}$ é o orifício de saída. O tracejado é o movimento da munição fora do corpo (cabeça).

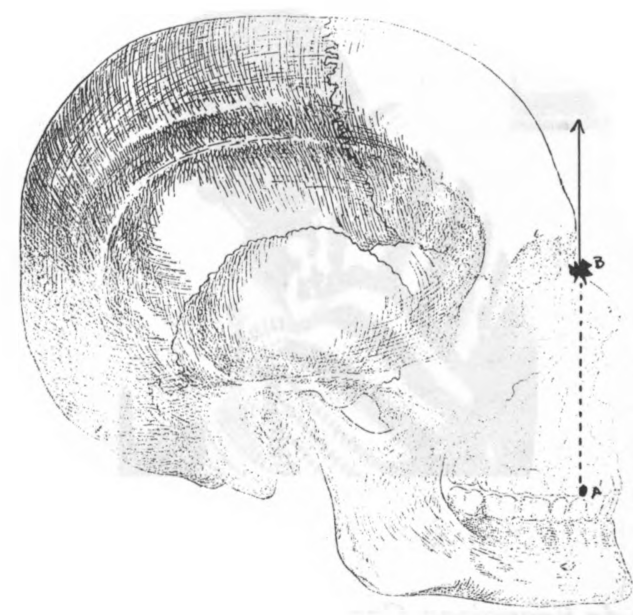

Modelo de perfil. O tracejado põe em evidência o percurso interior descrito pela bala. 


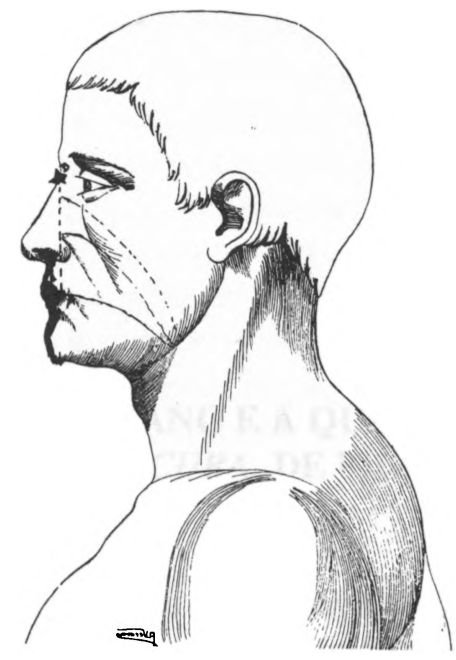

Modelo em posição de sentado. O fluxo hemorrágico, pela força da gravidade e posição do corpo é mais abundante pelas zonas posteriores, embora, também, deslize para as regiões anteriores. Posição em que o encontra Augusto Cabral.

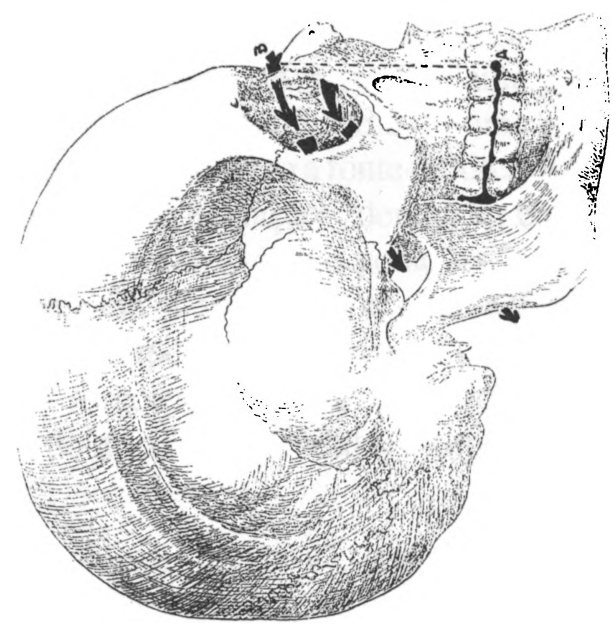

Modelo em posição de decúbito dorsal. O fluxo hemorrágico dirige-se para as zonas posteriores da cabeça devido à acção da gravidade. 